\title{
Fabrics of pre- and syntectonic granite plutons and chronology of shear zones in the Eastern Borborema Province, NE Brazil
}

\author{
Carlos J. Archanjo ${ }^{\text {a,* }}$, Maria Helena B.M. Hollanda ${ }^{a}$, Sérgio W.O. Rodrigues ${ }^{\text {a,b }}$, \\ Benjamim B.B. Neves ${ }^{a}$, Richard Armstrong ${ }^{c}$ \\ a Instituto de Geociências, Universidade de São Paulo, Rua do Lago 562, 05508-080 SãoPaulo, SP, Brazil \\ ${ }^{\mathrm{b}}$ Geological Survey Brazil (CPRM), Rua Costa 55, 01304-010 São Paulo, SP, Brazil \\ ${ }^{\mathrm{c}}$ Research School of Earth Sciences, The Australian National University, Canberra, ACT 0200, Australia
}

Received 12 June 2007; received in revised form 13 November 2007; accepted 20 November 2007

Available online 5 December 2007

\begin{abstract}
We used the fabrics of two granite plutons and U/Pb (SHRIMP) zircon ages to constrain the tectonic evolution of the E-trending Patos shear zone (Borborema Province, NE Brazil). The pre-tectonic Teixeira batholith consists of an amphibole leucogranite locally with aegirine-augite. Zircons from a syenogranite yielded crystallization ages of $591 \pm 5$ Ma. The batholith fabrics were determined by anisotropy of magnetic susceptibility (AMS) and mineral shape preferred orientation. The fabrics support pre-transcurrent batholith emplacement, as evidenced by: (i) magmatic/magnetic fabrics in low susceptibility $(<0.35 \mathrm{mSI})$ leucogranites highly discordant to the regional host rock structure, and (ii) concordant magnetic fabrics restricted to high susceptibility ( $>1 \mathrm{mSI}$ ) corridors connected to shear zones branching off from Patos. One of these satellite shear zones controlled the syntectonic emplacement of the Serra Redonda pluton, which yields a crystallization age of $576 \pm 3$ Ma. This late shearing event marks the peak regional deformation that, south of Patos, was coupled to crustal shortening nearly perpendicular to the shear belt. The chronology of the deformational events indicates that the major shear zones of the eastern Borborema are late structures active after the crustal blocks amalgamated.
\end{abstract}

(C) 2007 Elsevier Ltd. All rights reserved.

Keywords: Granite fabrics; Anisotropy of magnetic susceptibility; Shear zones; U/Pb geochronology; Tectonics

\section{Introduction}

The Patos and Pernambuco shear zones are major Neoproterozoic structures that played a fundamental role in deforming various crustal domains of the Borborema Province, northeastern Brazil (Fig. 1; Corsini et al., 1991; Vauchez and Silva, 1992; Davison and MacCarthy, 1995). These shear zones consist mainly of mylonites up to several kilometers wide, usually with partial melting of the host rocks. Many granite plutons linked with shear zones that splay off from Patos and Pernambuco show evidence of syntectonic emplacement (Vauchez and Neves, 1997; Archanjo et al., 2002; Weinberg et al., 2004). The relation between igneous rocks

\footnotetext{
* Corresponding author. Tel.: +55 1130914 657; fax: +55 1130914258.

E-mail address: archan@usp.br (C.J. Archanjo).
}

and shear zones is important as plutons may provide a means of determining the ages of the deformational events that make up an orogenic system. In particular, measuring the magmatic fabric pattern of bodies that usually "massive" in field studies can help address the link between magma emplacement and tectonics. Granites are usually anisotropic and have mineral fabric that may record the strain field of the magma during the final stages of emplacement. Abundant literature (Hutton, 1988; Brown and Solar, 1998; Paterson et al., 1998; Rosenberg, 2004) indicates that emplacement can be considered either tectonically controlled (syntectonic) if the magmatic fabric pattern is consistent with the regional strain field, or magma-pressure driven if the pattern is independent (post-tectonic). Although most granite appears homogeneous, measurements of the anisotropy of magnetic susceptibility (AMS) can provide details about fabric patterns. The 


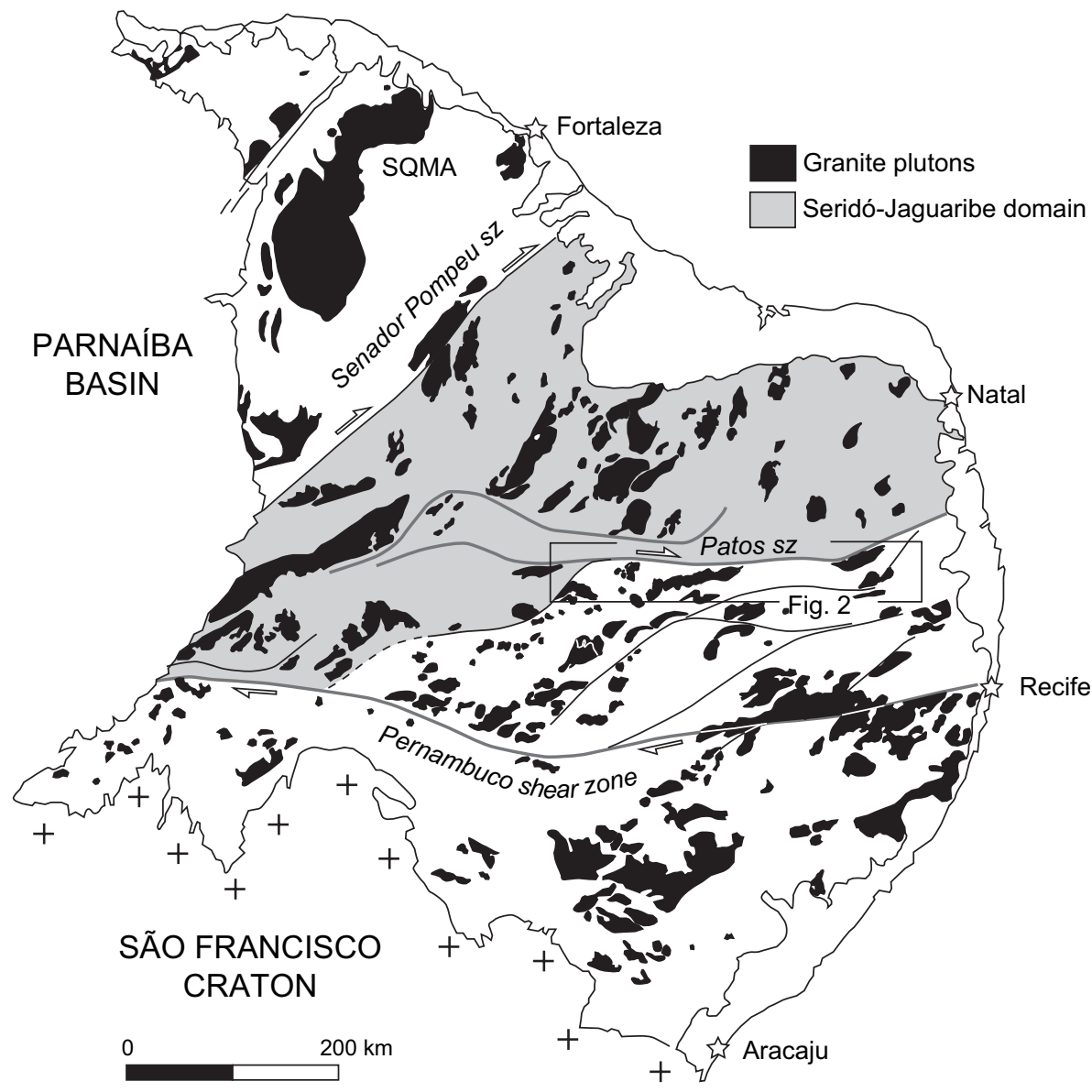

Fig. 1. Borborema Province (northeastern Brazil) highlighting the Brasiliano-Pan African plutonic rocks and shear zones. SQMA, Santa Quitéria Magmatic Arc.

theoretical background of AMS is described elsewhere (Borradaile and Henry, 1997; Bouchez, 1997); the essence is that magnetic fabric provides a fast and accurate determination of the igneous structure of granitoids.

The central and eastern segments of the Patos shear zone delimit two crustal blocks with different Neoproterozoic magmatic and kinematic histories. In the Seridó belt, located in the Seridó-Jaguaribe domain north of the Patos shear zone (Fig. 1), porphyritic granite-diorite plutons have remarkably uniform magmatic fabrics parallel to the $\mathrm{N}$ - to NE-trending regional extension (Archanjo et al., 2002). This syntectonic magmatism emplaced $580 \pm 5 \mathrm{Ma}$ must record the peak regional deformation. In contrast, plutons south of Patos have different compositions and crystallization ages (Ferreira et al., 1998; Guimarães et al., 2004). The oldest granodiorite to tonalite plutons of about 630 and $610 \mathrm{Ma}$ ages were emplaced before developing the transcurrent structures (Neves et al., 2006), and were likely related to a continental arc setting represented by the Santa Quitéria Magmatic Arc (SQMA, Fig. 1; Fetter et al., 2003). This magmatism has not been found in the Jaguaribe-Seridó domain, suggesting that the amalgamation of crustal blocks occurred late in the Borborema Province. A second magmatic event about $580 \mathrm{Ma}$ consists of a porphyritic granite and diorite association similar to that described in the Seridó-Jaguaribe domain. Its emplacement was coeval with strike-slip shearing in a bulk transpressive setting (Neves et al., 2006). Finally, a late magmatic episode of Early Cambrian (545-530 Ma) granite plutons and subvolcanic dikes was related to a generalized episode of crustal extension.

This paper focuses on the plutons of Teixeira and Serra Redonda, located just south of the Patos shear zone. It combines $\mathrm{U} / \mathrm{Pb}$ SHRIMP zircon geochronology and AMS to constrain the timing of emplacement and its relation to the regional strain field. Magmatic and host rock fabrics allow us to postulate that the Patos and its satellite shear zones are late deformational structures that combined crustal-scale shearing and bulk regional shortening at a high angle to major faults.

\section{Geological setting}

The central and eastern Patos and São José dos Cordeiros shear zones enclose an ENE-trending corridor of Early Neoproterozoic rocks regionally called the Alto Pajeú belt (Fig. 2; Brito Neves et al., 2000). It consists of orthogneiss, intermediate to felsic metavolcanic and pelitic to psamitic metasediments between 1.1 and $0.9 \mathrm{Ga}$ old (Brito Neves et al., 2001). Shear zones separate the Alto Pajeú belt from the Paleoproterozoic basement and, to the west, from Neoproterozoic low grade pelitic metasediments. The contact between the metapelites 


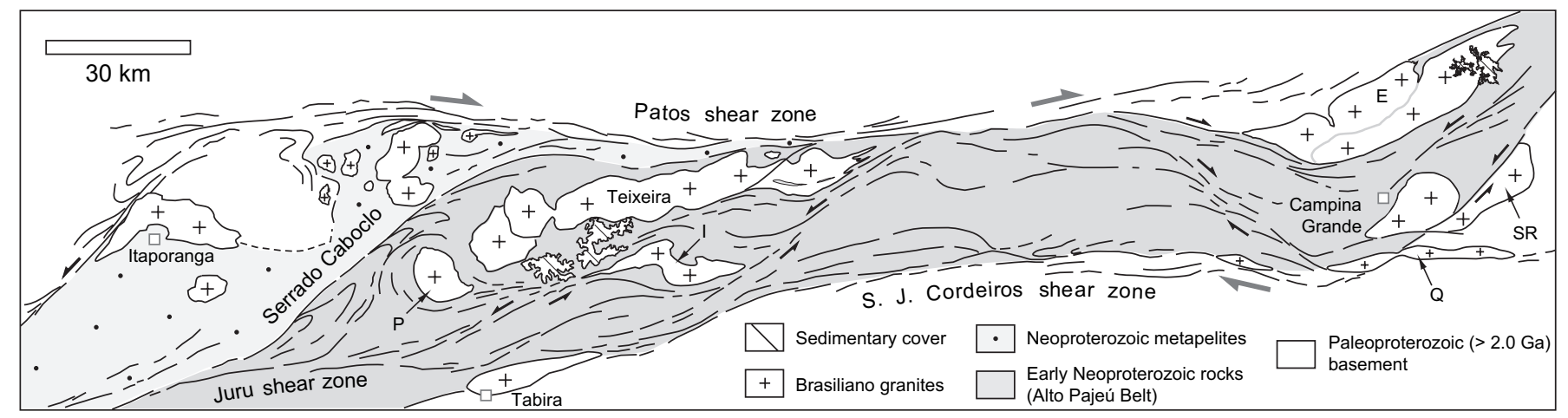

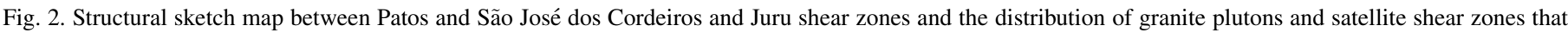
crosscut the Alto Pajeú belt. E, Esperança; SR, Serra Redonda; Q, Queimadas; I, Itapetim; P, Palmeira.

and the Alto Pajeú belt occurs along the Serra do Caboclo mylonite zone, which joins the shear zones of Patos to the north and Juru to the south. The belt is limited to the east by the NEtrending Galante shear zone, which, approaching the Atlantic coast, joins the Patos mylonites. The Teixeira batholith and Serra Redonda pluton are located along lithological contacts; between the metasedimentary rocks and orthogneisses of the Alto Pajeú belt and between the Early Neoproterozoic orthogneiss and the Paleoproterozoic basement, respectively.

The shear zones that crosscut the Alto Pajeú Belt form a conjugate set, particularly well-developed around the plutons of Campina Grande (Fig. 2). They consist of medium- to highgrade mylonites, usually with steep foliations and subhorizontal stretching lineations (Vauchez et al., 1995; Archanjo and Fetter, 2004). Far from these mylonitic corridors, the foliation becomes anastomosed around lower strain rocks, some forming domes cored by granite plutons (Palmeira and Itapetim, Fig. 2). Some granite plutons, like Teixeira, Tabira, Serra Redonda and Queimadas, form elongated sheets parallel to the host regional foliation. The regional transcurrent structures overprint an older thrust fabric better recognized to the south of São José dos Cordeiros shear zone (Neves et al., 2006). In Campina Grande, the development of the transcurrent fabric as well the metamorphic peak appears to be related to the emplacement of coarse porphyritic granite-diorite plutons of Campina Grande (581 \pm 2 Ma, Guimarães et al., 2004) and Queimadas dike (570 $\pm 24 \mathrm{Ma}$, Almeida et al., 2002).

\subsection{The Teixeira batholith}

The ENE-trending elongate Teixeira batholith, $80 \mathrm{~km}$ long and approximately $10 \mathrm{~km}$ wide, is an equigranular, leucocratic, granite to quartz-syenite in composition, except to the west in Mãe D'Água in that it is porphyritic (Fig. 3). As its texture and mineralogy differ from the remaining batholith, we hereafter call it the Mãe D'Água pluton. In map view, the pinch-and-swell shape of the batholith is related to the conjugate fractures and fault zones that crosscut the body. The two major necked regions allow to informally divide the Teixeira batholith to the west and east into the Mãe D'Água pluton and the Jabre, Teixeira, São Sebastião and Pedra
D’Água domains, respectively (Fig. 3). The Mãe-D’Água pluton consists of biotite and green hornblende porphyritic granite. Opaque grains are not visible in thin section. The Jabre and Teixeira form roughly wedge-shaped domains limited by the Tendó shear zone. They consist of medium-grained biotiteamphibole monzogranite to syenogranite. Microstructure is magmatic to sub-magmatic (Bouchez et al., 1992), but near the southern contact with the host orthogneiss it develops a gneissic fabric. Opaque grains are not visible in thin sections within the Jabre and Teixeira domains, except close to sheared and fractured zones, where they usually occur with mafic minerals. The São Sebastião domain forms a roughly triangular body limited to the west and to the east, respectively, by the Guaritas fracture zone and the Itapetim shear zone (Fig. 3). It consists mostly of a medium-grained Fe-hastingsite syenogranite. Unlike the Jabre and Teixeira domains, opaque grains are visible in thin section, and biotite is absent or occurs locally as an accessory mineral. The microstructure is dominantly submagmatic, consisting of fractured feldspar plagioclase with tapered Carlsbad twins to locally gneissic consisting of elongate ribbons with finely recrystallized quartz and feldspar. Opaque grains are usually found with amphibole generally infilling internal microfractures. An aegirine-augite quartz syenite with blue amphibole occurs in the eastern border of the São Sebastião domain in contact with the Itapetim shear zone. The pyroxene shows a deep green pleochroism and, in contrast with the amphibole, has a large optical axial angle. Microstructure is submagmatic with pyroxene and amphibole grains exhibiting a fairly good shape preferred orientation. The aegirine-augite quartz syenite is an equigranular, leucocratic body texturally similar to the São Sebastião, Teixeira and Jabre domains.

Finally, the Pedra D'Água domain consists of a set of elliptical to elongate biotite-amphibole granite sheets located between the Itapetim and Taperoá shear zones (Fig. 3). Disrupted lenses of host rocks can be found between the granite sheets that, approaching the eastern host rock contact, develop a "dactilict-type" structure consisting of alternating orthogneisses and granite dikes. The sheets are entirely foliated. The lineation, consisting of stretched mafic aggregates, plunges gently throughout. Since its gneissic fabric can be 


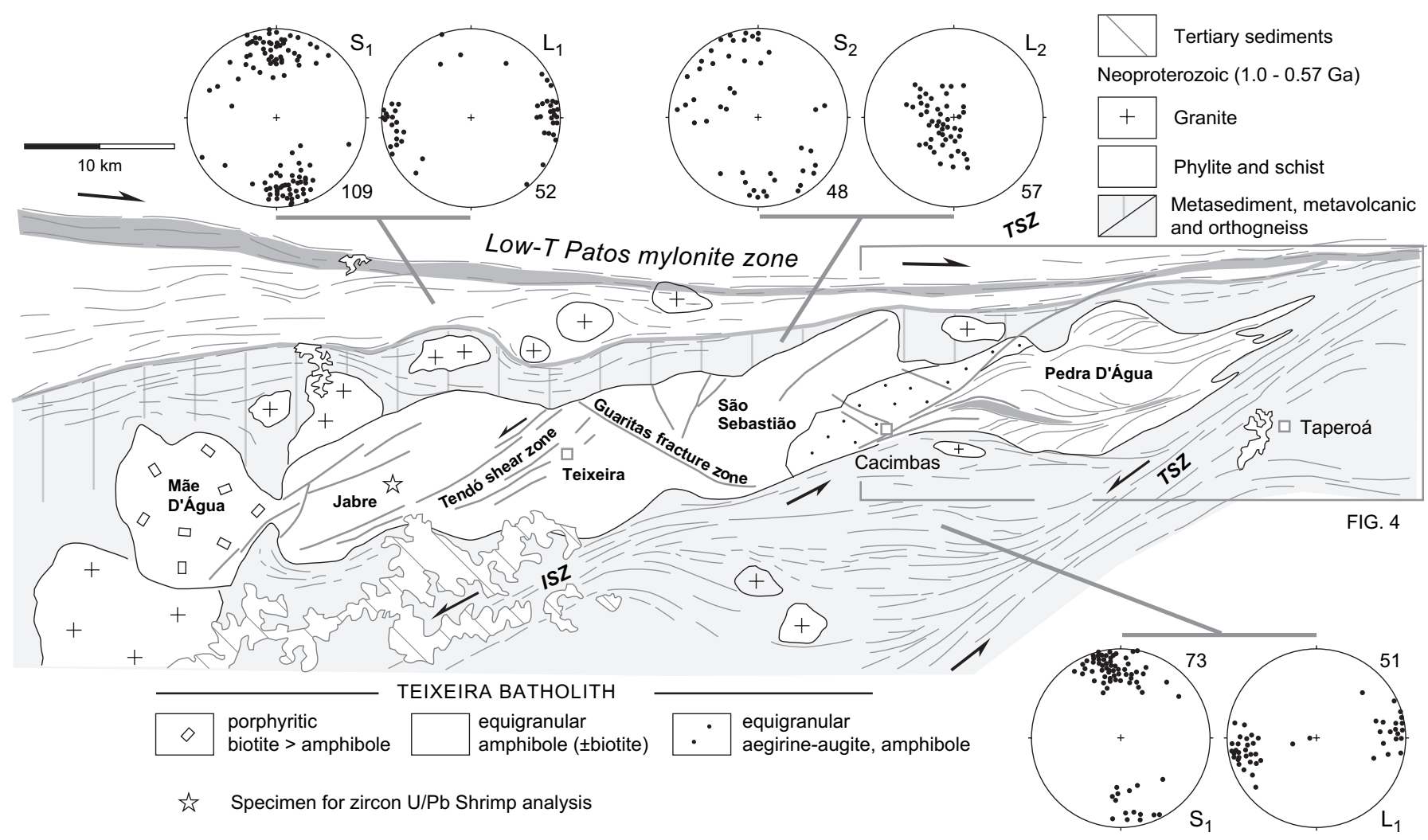

Fig. 3. Structural map of the Teixeira batholith and host rocks. S, foliation pole; L, lineation. Schmidt stereogram, lower hemisphere. ISZ and TSZ correspond to, respectively, the Itapetim and Taperoá shear zones.

easily measured in the field, these sheets were not sampled for AMS.

\subsubsection{Country rocks structures and shear zone kinematics}

The batholith occupies the contact zone between Early Neoproterozoic metasediments and orthogneisses, but its eastern termination (Pedra D'Água domain) is surrounded by orthogneiss. Further north, the metasediments are juxtaposed with Neoproterozoic metapelites by a sheared contact. The batholith pinches against retrogressed greenschist mylonites of the Patos shear zone. In the metapelite, the fabric is similar to that found along the Patos mylonites. It consists of a steeply dipping fanlike axial-plane foliation $\left(\mathrm{S}_{1}\right)$ transposing tight to isoclinal normal folds. Stretching and intersection lineations $\left(\mathrm{L}_{1}\right)$ are normally subhorizontal and parallel to fold axes (Fig. 3). The same fabric style occurs to the south in the host orthogneiss. The gneissic foliation trends E-W to ENE and progressively bends to $\mathrm{NE}$ approaching the major mylonitic corridors of the Itapetim and Taperoá shear zones. These enclose the Pedra D'Água domain to form sigma-type granite sheets consistent with the left-lateral movement of NE-trending shear zones (Fig. 4). The foliation within the sheets is subvertical, parallel to the flattening plane formed by the left-lateral shear zones. A different fabric style marks the metasediments of the northern contact of the batholith. There, an asymmetric crenulation $\left(\mathrm{D}_{2}\right)$ develops vertical folds with vergence to the east. An anastomosed to planar NEtrending foliation $\left(\mathrm{S}_{2}\right)$ dips steeply, while the lineation $\left(\mathrm{L}_{2}\right)$, defined by intersection surfaces (bedding $\times \mathrm{S}_{1}$ ) and mineral alignment, usually plunges in a down-dip (Fig. 3).

\subsection{The Serra Redonda pluton}

The Serra Redonda pluton is an elongate intrusive body approximately $45 \mathrm{~km}$ long and $6 \mathrm{~km}$ wide, consisting of coarse porphyritic granite and diorite. The diorite occupies the eastern border of the pluton, either in contact with the SE-dipping Bacamarte thrust or as a small elongate stock in contact with the Galante shear zone. Near the contact the coarse porphyritic granite and diorite are converted to mylonite or protomylonite. The transcurrent Galante shear zone places the Paleoproterozoic basement against the Early Neoproterozoic and places the Serra Redonda in contact with the Campina Grande pluton. The latter is also composed of coarse porphyritic granite and diorite, which led Almeida et al. (2002) to consider them a single magmatic body. The coarse texture and alignment of feldspar phenocrysts allowed the magmatic foliation of these bodies to be mapped. The "teardrop" shape of the Campina Grande pluton shows concentric foliations dipping inward, while foliations in Serra Redonda are roughly parallel to the pluton elongation (Fig. 5, inset). Along the Galante shear zone, foliation is vertical. In the center and towards the eastern border, the foliation dips moderately to the SE. The magmatic lineation, usually preserved in the internal parts of the pluton, trends NE, parallel to the stretching direction of the Galante shear zone. 


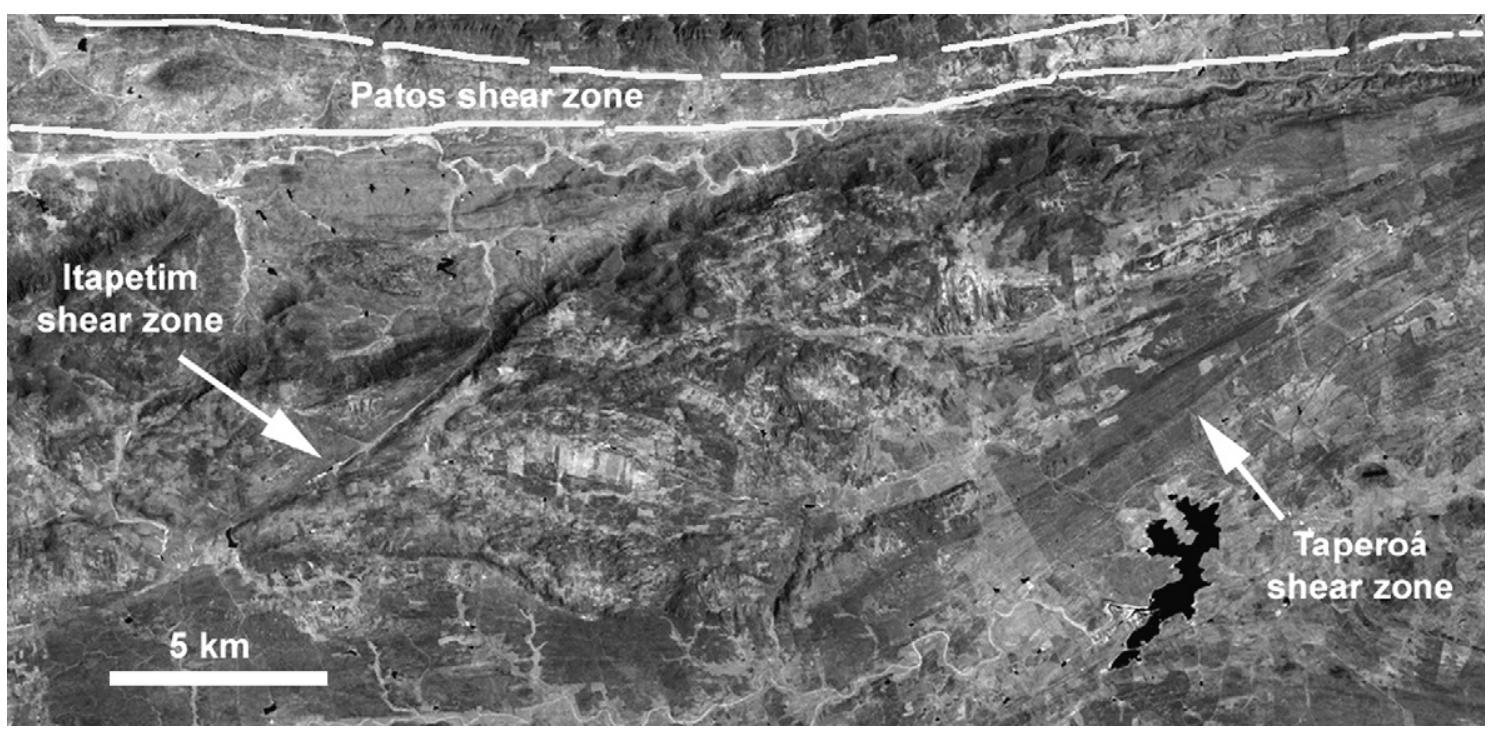

Fig. 4. Satellite image of the eastern termination of the Teixeira batholith (Pedra D'Água domain, see localization on Fig. 3). Note the sigma shape of the leucogranite sheets between Patos, Itapetim and Taperoá shear zone system.

\subsubsection{Country rocks structures and shear zone kinematics}

Host rock fabrics in the Campina Grande and Serra Redonda plutons vary in metamorphic degree and orientation. The foliation, generally parallel to gneissic banding of the Paleoproterozoic basement, dips moderately to the southeast in the eastern domain (Fig. 5). Down-dip lineations occur principally where banded gray gneisses are thrust over diorites. Quartz-feldspatic veins and melted pockets crosscutting the foliation of the hangingwall rocks attest to high temperature conditions. A few meters above the contact zone, diorite dikes cut the banded gneisses at a low to moderate angle. The dikes usually display a pinch-and-swell shape, while drag folds form in the wall rock foliation (Fig. 6). These features indicate that the dikes were emplaced in the final stages of the emplacement of Paleoproterozoic rocks over the granite footwall.

The Paleoproterozoic basement and the Alto Pajeú belt are juxtaposed by the Galante shear zone, which, together with the Matinhas shear zone, forms the regional NE-trending sinistral branch of conjugate shear structures (Archanjo and Fetter, 2004). These are characterized by low- to medium-grade steeply dipping mylonites. Stretching lineations are subhorizontal (Fig. 5). Between the Galante and Matinhas shear zones (northeast domain), the host rock foliation forms gentle to open folds distributed around a zone axis parallel to the subhorizontal NE-trending lineation. The foliation steepens progressively approaching the shear zones. Near the Queimadas dike to the south, the foliation and lineation, including the Galante shear zone, bend progressively to merge with the São José dos Cordeiros shear zone (Fig. 2). Regional fabrics and shear zone kinematics are consistent with a bulk NNW-SSE shortening direction, which, in addition could have caused the boudinage of the Queimadas dike. Because the magmatic fabric of the Serra Redonda pluton remains coaxial with the regional strain field, we conclude that the compressive structures around Campina Grande were formed during or shortly after the emplacement of the pluton.

\subsection{U/Pb zircon geochronology}

We obtained U/Pb SHRIMP ages for two samples, a hornblende leucogranite from the Jabre domain (Teixeira batholith) and a porphyritic granite (Serra Redonda pluton). Samples were processed using a jaw crusher, wifley table, heavy liquids (bromoform and methylene iodide) and a Frantz isodynamic separator at the Geochronology Research Center, University of São Paulo. Representative zircon grains were hand picked under a binocular microscope, mounted in epoxy resin and polished to approximately half their thickness to expose internal morphological features. Zircon standards were included in the mounts and analyzed sequentially with the unknowns. Transmitted and reflected light microscopy and cathodoluminescence imaging were taken for the selected zircon grains to determine internal complexities before analysis. The study focused on igneous growth sectors to obtain zircon crystallization ages.

Analyses were performed on a SHRIMP II at the Research School of Earth Sciences (RSES) at the Australian National University, Canberra. The analytical procedure is detailed in Williams (1998). Data were collected and reduced as described by Williams and Claesson (1987) and Compston et al. (1992), using the SQUID Excel macro of Ludwig (2000). U/Pb ratios were referenced to the TEM standard (417 Ma), and $\mathrm{U}$ and Th concentrations were determined with those measured in RSES zircon standard SL13. Correction for common $\mathrm{Pb}$ was made using measured ${ }^{204} \mathrm{~Pb}$ and assuming the model $\mathrm{Pb}$ composition from Stacey and Kramers (1975). Errors in the isotopic ratios and ages are quoted in Table 1 at $1 \sigma$ errors. Concordia ages and statistical assessments were performed using the geochronological ISOPLOT/Excel 3.00 software of Ludwig (2003); errors are given at the $95 \%$ confidence level.

Zircons extracted from sample JAB1 (Teixeira batholith) are prismatic, from 150 to $250 \mu \mathrm{m}$ in length and with variable aspect ratios. The color varies between clear, pinkish and light brown. All grains display typical primary oscillatory zoning; 


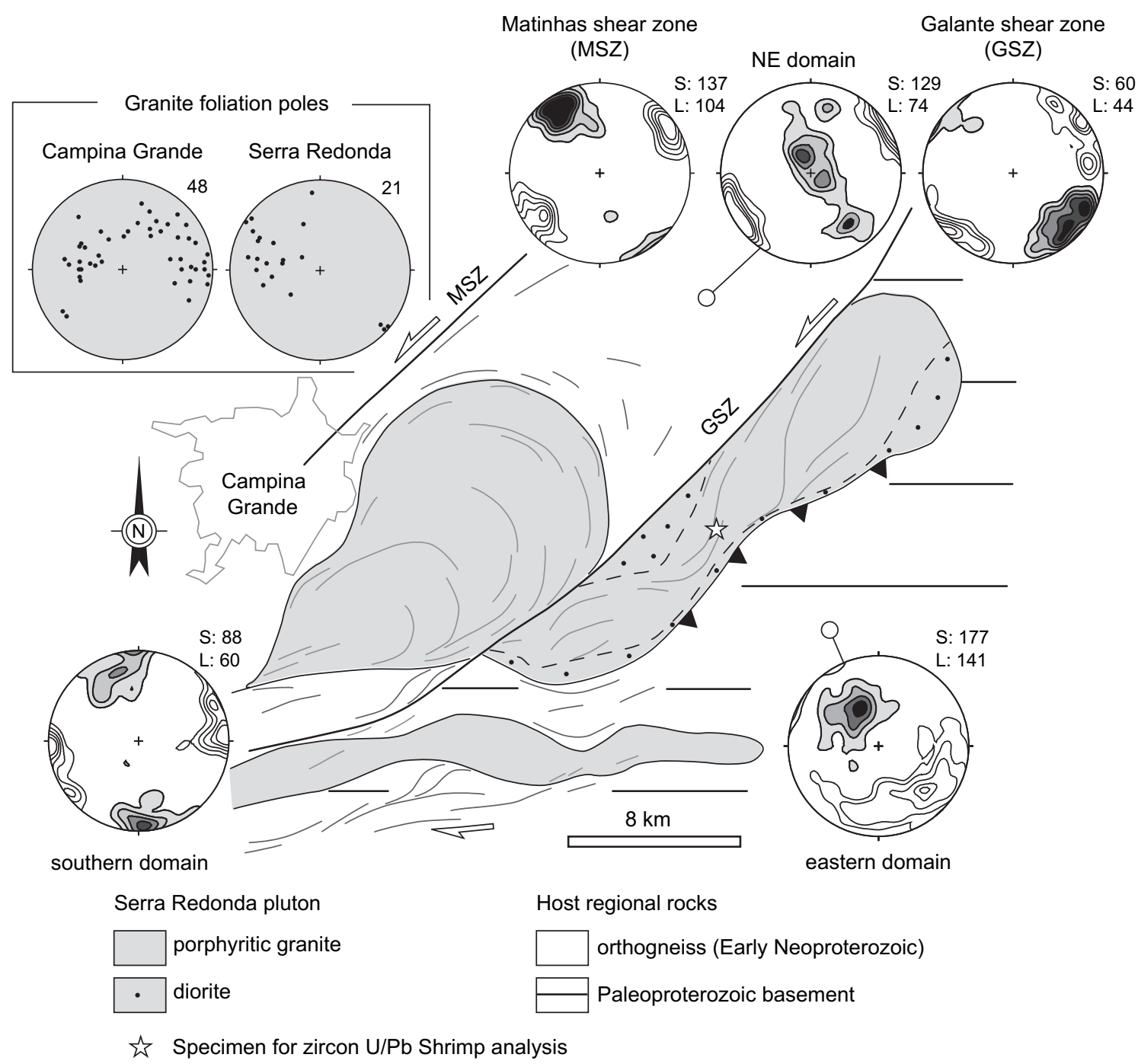

Fig. 5. Structural map of the Campina Grande Magmatic Complex and country rocks. In the orientation stereograms the foliation pole (S, shaded area) and lineation (L) are shown on Schmidt net (lower hemisphere). Inset: the planar magmatic fabric of Campina Grande and Serra Redonda plutons. MSZ and GSZ correspond to, respectively, the Matinhas and Galante shear zones.

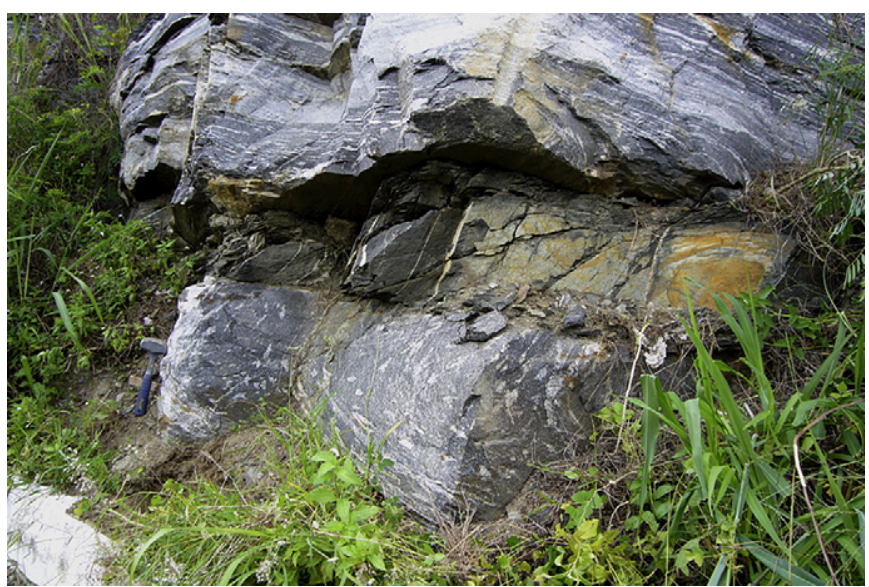

Fig. 6. Drag-fold in banded gneiss hosting a diorite dike. The banded gneiss forms the hanging wall rocks thrusted on porphyritic granite and diorite of the Serra Redonda pluton. The feature suggest the dike crosscut the gneissic banding in the latest ductile stage of the thrust movement. some of them show a crosscutting relationship with a second, later, magmatic domain. Cores occur in most of the grains. These are rounded in shape; generally, complex internal structures are absent. Radial microfractures from the cores are also present, probably induced by metamictization-related volume expansion of the crystal lattice (e.g. Lee and Tromp, 1995). Fifteen analyses were performed on different zircon grains (Table 1) and plotted on a conventional Wetherill U/Pb Concordia diagram (Fig. 7). Eight analyses are significantly discordant, and were excluded from the age calculation. Two analyses (spots \#11, \#15) with high ${ }^{207} * \mathrm{~Pb} /{ }^{206} * \mathrm{~Pb}$ ages, are attributed to inherited, old zircons. The five remaining analyses (spots $\# 1$, \#3, \#4, \#5, \#6) define a Concordia age of $591 \pm 5.3 \mathrm{Ma}$, the best estimate for crystallization of the Teixeira pluton.

Zircons extracted from the Serra Redonda pluton (sample SR1) are prismatic and euhedral, between 200 to $300 \mu \mathrm{m}$ in length. The color varies from pinkish to light brown. CL images reveal typical magmatic oscillatory zoning. Eighteen zircon grains were dated (see Table 1). Most of the analytical points 
Table 1

$\mathrm{U} / \mathrm{Pb}$ SHRIMP isotopic data on zircons from the Teixeira and Serra Redonda granite plutons (NE Brazil)

\begin{tabular}{|c|c|c|c|c|c|c|c|c|c|c|c|c|c|c|c|c|c|c|c|c|c|c|c|}
\hline $\begin{array}{l}\text { Grain } \\
\text { Spot }\end{array}$ & ${ }^{\%}{ }^{206} \mathrm{~Pb}_{\mathrm{c}}$ & U ppm & $\begin{array}{l}\text { Th } \\
\text { ppm }\end{array}$ & $\begin{array}{l}{ }^{232} \mathrm{Th} / \\
{ }^{238} \mathrm{U}\end{array}$ & $\begin{array}{l}{ }^{206} \mathrm{~Pb}^{*} \\
\mathrm{ppm}\end{array}$ & $\begin{array}{l}{ }^{206} \mathrm{~Pb} /{ }^{238} \mathrm{~L} \\
\mathrm{Age}^{\mathrm{a}}\end{array}$ & & $\begin{array}{l}{ }^{207} \mathrm{~Pb} /^{2} \\
\mathrm{Age}^{\mathrm{a}}\end{array}$ & & $\begin{array}{l}\% \\
\text { Discor } \\
\text { dant }\end{array}$ & $\begin{array}{l}\text { Total } \\
{ }^{238} \mathrm{U} / \\
{ }^{206} \mathrm{~Pb}\end{array}$ & $\pm \%$ & $\begin{array}{l}\text { Total } \\
{ }^{207} \mathrm{~Pb} / \\
{ }^{206} \mathrm{~Pb}\end{array}$ & $\pm \%$ & $\begin{array}{l}{ }^{238} \mathrm{U} / \\
{ }^{206} \mathrm{~Pb}^{\mathrm{a}}\end{array}$ & $\pm \%$ & $\begin{array}{l}{ }^{207} \mathrm{~Pb}^{* /} \\
{ }^{206} \mathrm{~Pb}^{* \mathrm{a}}\end{array}$ & $\pm \%$ & $\begin{array}{l}{ }^{207} \mathrm{~Pb}^{* /} \\
{ }^{235} \mathrm{U}^{\mathrm{a}}\end{array}$ & $\pm \%$ & $\begin{array}{l}{ }^{206} \mathrm{~Pb}^{* /} \\
{ }^{238} \mathrm{U}^{\mathrm{a}}\end{array}$ & $\pm \%$ & $\begin{array}{l}\text { err. } \\
\text { corr }\end{array}$ \\
\hline \multicolumn{24}{|c|}{ Teixeira } \\
\hline 1.1 & 0.26 & 695 & 158 & 0.24 & 58.1 & 596.7 & \pm 3.9 & 597 & \pm 20 & 0 & 10.285 & 0.68 & 0.06195 & 0.54 & 10.312 & 0.68 & 0.05983 & 0.92 & 0.8 & 1.1 & 0.09698 & 0.68 & 0.596 \\
\hline 2.1 & 0.52 & 603 & 270 & 0.46 & 48.7 & 576.4 & \pm 3.9 & 596 & \pm 25 & 3 & 10.637 & 0.71 & 0.064 & 0.58 & 10.692 & 0.71 & 0.05979 & 1.1 & 0.771 & 1.3 & 0.09353 & 0.71 & 0.528 \\
\hline 3.1 & 0.53 & 832 & 225 & 0.28 & 69.3 & 593.6 & \pm 3.9 & 625 & \pm 22 & 5 & 10.313 & 0.68 & 0.0649 & 0.59 & 10.367 & 0.68 & 0.0606 & 1 & 0.806 & 1.2 & 0.09646 & 0.68 & 0.552 \\
\hline 4.1 & 0.94 & 837 & 170 & 0.21 & 69.2 & 587.1 & \pm 4.6 & 598 & \pm 38 & 2 & 10.389 & 0.8 & 0.06751 & 0.47 & 10.488 & 0.81 & 0.0599 & 1.7 & 0.787 & 1.9 & 0.09535 & 0.81 & 0.423 \\
\hline 5.1 & 0.61 & 902 & 180 & 0.21 & 73.7 & 582.7 & \pm 4.4 & 654 & \pm 21 & 11 & 10.507 & 0.78 & 0.06634 & 0.46 & 10.571 & 0.78 & 0.06141 & 10 & 0.801 & 1.3 & 0.0946 & 0.78 & 0.616 \\
\hline 6.1 & 0.20 & 487 & 87 & 0.19 & 40 & 587.2 & \pm 4 & 599 & \pm 31 & 2 & 10.464 & 0.7 & 0.06152 & 1.2 & 10.485 & 0.7 & 0.05987 & 1.4 & 0.787 & 1.6 & 0.09537 & 0.7 & 0.437 \\
\hline 7.1 & 3.53 & 1053 & 787 & 0.77 & 85.2 & 560.6 & \pm 4.6 & 576 & \pm 49 & 3 & 10.618 & 0.82 & 0.08804 & 0.67 & 11.007 & 0.86 & 0.0592 & 2.2 & 0.742 & 2.4 & 0.09085 & 0.86 & 0.358 \\
\hline 8.1 & 4.89 & 1017 & 502 & 0.51 & 81.4 & 547.7 & \pm 3.9 & 523 & \pm 70 & -5 & 10.727 & 0.67 & 0.0977 & 1.1 & 11.278 & 0.75 & 0.0578 & 3.2 & 0.707 & 3.3 & 0.08867 & 0.75 & 0.229 \\
\hline 9.1 & 2.63 & 1040 & 800 & 0.79 & 70.8 & 478.9 & \pm 3.3 & 536 & \pm 82 & 11 & 12.626 & 0.67 & 0.0795 & 2 & 12.967 & 0.71 & 0.0582 & 3.8 & 0.619 & 3.8 & 0.07712 & 0.71 & 0.186 \\
\hline 10.1 & 2.15 & 518 & 152 & 0.30 & 38.2 & 520.9 & \pm 5.9 & 623 & \pm 79 & 16 & 11.63 & 1.1 & 0.0779 & 1.9 & 11.88 & 1.2 & 0.0605 & 3.7 & 0.702 & 3.8 & 0.08416 & 1.2 & 0.305 \\
\hline 11.1 & 2.90 & 926 & 247 & 0.28 & 198 & 1396.9 & \pm 9.5 & 1910 & \pm 31 & 27 & 4.013 & 0.71 & 0.1409 & 0.96 & 4.133 & 0.75 & 0.117 & 1.8 & 3.902 & 1.9 & 0.242 & 0.75 & 0.395 \\
\hline 12.1 & 6.48 & 1758 & 977 & 0.57 & 128 & 492.5 & \pm 5.4 & 640 & \pm 320 & 23 & 11.78 & 0.65 & 0.1134 & 4.6 & 12.6 & 1.1 & 0.061 & 15 & 0.668 & 15 & 0.07939 & 1.1 & 0.078 \\
\hline 13.1 & 1.49 & 894 & 223 & 0.26 & 71.9 & 569 & \pm 3.7 & 636 & \pm 45 & 11 & 10.676 & 0.67 & 0.07302 & 1.3 & 10.837 & 0.69 & 0.0609 & 2.1 & 0.775 & 2.2 & 0.09228 & 0.69 & 0.313 \\
\hline 14.1 & 3.82 & 836 & 377 & 0.47 & 66.9 & 553.2 & \pm 3.9 & 566 & \pm 57 & 2 & 0.14 & 0.68 & 0.09013 & 0.73 & 11.161 & 0.73 & 0.059 & 2.6 & 0.729 & 2.7 & 0.0896 & 0.73 & 0.271 \\
\hline 15.1 & 1.02 & 522 & 118 & 0.23 & 53 & 714.1 & \pm 7.7 & 1276 & \pm 86 & 44 & 8.449 & 1.1 & 0.0915 & 3.9 & 8.536 & 1.1 & 0.0833 & 4.4 & 1.345 & 4.5 & 0.1171 & 1.1 & 0.252 \\
\hline \multicolumn{24}{|c|}{ Serra Redonda } \\
\hline 1.1 & 0.22 & 408 & 208 & 0.53 & 33.3 & 584.2 & \pm 4 & 578 & \pm 23 & -1 & 10.52 & 0.72 & 0.06109 & 0.71 & 10.543 & 0.72 & 0.0593 & 1.1 & 0.7756 & 1.3 & 0.09485 & 0.72 & 0.565 \\
\hline 2.1 & 0.15 & 456 & 251 & 0.57 & 36.7 & 576.6 & \pm 4 & 575 & \pm 20 & 0 & 10.671 & 0.73 & 0.06046 & 0.68 & 10.688 & 0.73 & 0.05921 & 0.91 & 0.7639 & 1.2 & 0.09357 & 0.73 & 0.628 \\
\hline 3.1 & 0.19 & 488 & 258 & 0.55 & 39.1 & 573.9 & \pm 3.9 & 581 & \pm 22 & 1 & 10.721 & 0.7 & 0.06092 & 0.65 & 10.741 & 0.71 & 0.05939 & 1 & 0.7624 & 1.2 & 0.0931 & 0.71 & 0.571 \\
\hline 4.1 & 0.00 & 438 & 243 & 0.57 & 36.8 & 601.1 & \pm 4.2 & 616 & \pm 15 & 2 & 10.233 & 0.74 & 0.06034 & 0.7 & 10.233 & 0.74 & 0.06034 & 0.7 & 0.8131 & 1 & 0.09772 & 0.74 & 0.724 \\
\hline 5.1 & 0.05 & 595 & 412 & 0.72 & 47.5 & 572.3 & \pm 3.9 & 591 & \pm 23 & 3 & 10.765 & 0.7 & 0.0601 & 0.98 & 10.771 & 0.7 & 0.05966 & 1.1 & 0.7637 & 1.3 & 0.09284 & 0.7 & 0.554 \\
\hline 6.1 & 0.14 & 374 & 194 & 0.53 & 30.2 & 578.6 & \pm 4 & 599 & \pm 20 & 3 & 10.635 & 0.72 & 0.06101 & 0.73 & 10.65 & 0.72 & 0.05986 & 0.93 & 0.775 & 1.2 & 0.0939 & 0.72 & 0.616 \\
\hline 7.1 & 1.30 & 631 & 334 & 0.55 & 50.6 & 567.6 & \pm 3.8 & 570 & \pm 52 & 0 & 10.724 & 0.68 & 0.06965 & 0.99 & 10.865 & 0.7 & 0.0591 & 2.4 & 0.75 & 2.5 & 0.09204 & 0.7 & 0.282 \\
\hline 8.1 & 0.42 & 535 & 265 & 0.51 & 42.9 & 572.3 & \pm 4.9 & 598 & \pm 25 & 4 & 10.725 & 0.88 & 0.06332 & 0.6 & 10.771 & 0.89 & 0.05986 & 1.1 & 0.766 & 1.4 & 0.09284 & 0.89 & 0.615 \\
\hline 9.1 & 0.22 & 539 & 301 & 0.58 & 43.7 & 580.8 & \pm 3.9 & 568 & \pm 21 & -2 & 10.583 & 0.69 & 0.06086 & 0.61 & 10.607 & 0.7 & 0.05903 & 0.94 & 0.7673 & 1.2 & 0.09428 & 0.7 & 0.594 \\
\hline 10.1 & 0.34 & 478 & 270 & 0.58 & 38.5 & 575.2 & \pm 3.9 & 528 & \pm 28 & -9 & 10.678 & 0.71 & 0.06076 & 0.67 & 10.715 & 0.71 & 0.05795 & 1.3 & 0.746 & 1.4 & 0.09333 & 0.71 & 0.492 \\
\hline 11.1 & 0.10 & 567 & 296 & 0.54 & 45 & 569 & \pm 3.9 & 592 & \pm 18 & 4 & 10.825 & 0.71 & 0.06052 & 0.69 & 10.837 & 0.71 & 0.05968 & 0.82 & 0.7593 & 1.1 & 0.09228 & 0.71 & 0.654 \\
\hline 12.1 & 0.02 & 491 & 259 & 0.54 & 39.3 & 573.8 & \pm 3.8 & 596 & \pm 14 & 4 & 10.739 & 0.7 & 0.05995 & 0.63 & 10.741 & 0.7 & 0.05979 & 0.66 & 0.7675 & 0.96 & 0.0931 & 0.7 & 0.727 \\
\hline 13.1 & 0.13 & 522 & 249 & 0.49 & 42.1 & 577.7 & \pm 4 & 597 & \pm 22 & 3 & 10.653 & 0.71 & 0.06085 & 0.62 & 10.667 & 0.72 & 0.05981 & 1 & 0.773 & 1.2 & 0.09375 & 0.72 & 0.581 \\
\hline 14.1 & 0.23 & 503 & 267 & 0.55 & 41 & 582.9 & \pm 4 & 579 & \pm 30 & -1 & 10.543 & 0.72 & 0.0612 & 1.1 & 10.568 & 0.72 & 0.05933 & 1.4 & 0.774 & 1.5 & 0.09463 & 0.72 & 0.468 \\
\hline 15.1 & 0.14 & 458 & 236 & 0.53 & 36.5 & 571.7 & \pm 4.9 & 586 & \pm 24 & 2 & 10.768 & 0.9 & 0.06067 & 0.67 & 10.783 & 0.9 & 0.05953 & 1.1 & 0.761 & 1.4 & 0.09273 & 0.9 & 0.631 \\
\hline 16.1 & 0.14 & 522 & 275 & 0.54 & 41.6 & 572.1 & \pm 5.4 & 596 & \pm 23 & 4 & 10.76 & 0.98 & 0.06093 & 0.63 & 10.77 & 0.99 & 0.05979 & 1 & 0.765 & 1.4 & 0.09281 & 0.99 & 0.687 \\
\hline 17.1 & 0.17 & 587 & 353 & 0.62 & 45.9 & 560.6 & \pm 5.2 & 582 & \pm 26 & 4 & 10.99 & 0.96 & 0.06082 & 0.6 & 11.01 & 0.96 & 0.05942 & 1.2 & 0.744 & 1.5 & 0.09085 & 0.96 & 0.628 \\
\hline 18.1 & 0.15 & 462 & 229 & 0.51 & 36.2 & 562 & \pm 3.8 & 584 & \pm 26 & 4 & 10.962 & 0.71 & 0.06072 & 0.98 & 10.979 & 0.71 & 0.05946 & 1.2 & 0.747 & 1.4 & 0.09109 & 0.71 & 0.508 \\
\hline
\end{tabular}

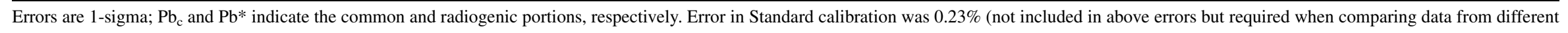
mounts).

${ }^{\text {a }}$ Common $\mathrm{Pb}$ corrected using measured ${ }^{204} \mathrm{~Pb}$. 
A

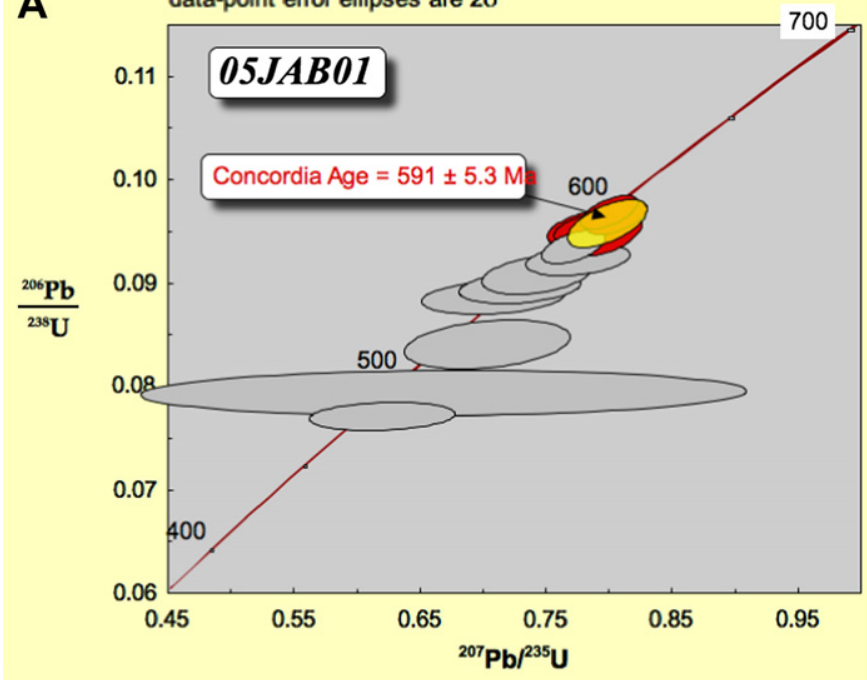

B

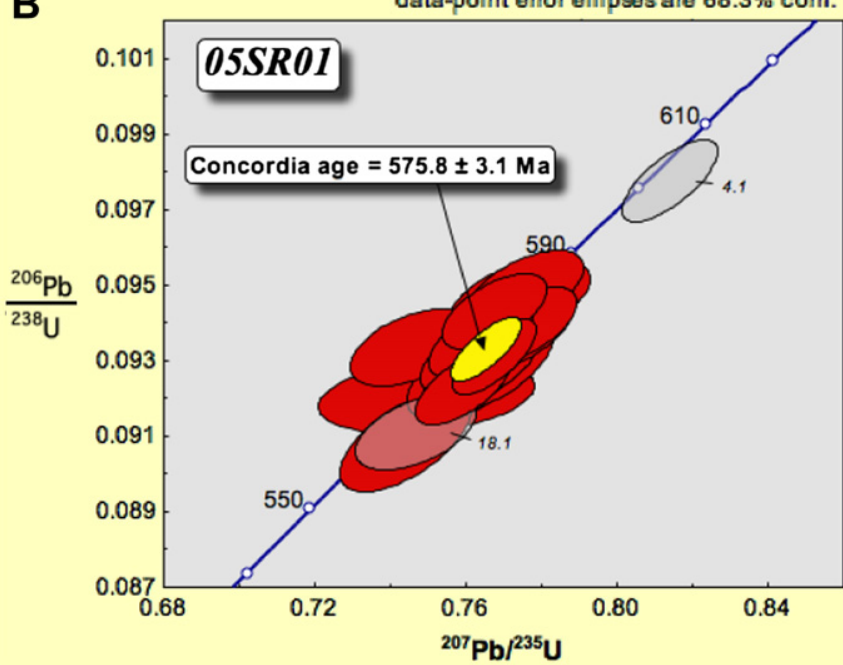

Fig. 7. Wetheril $\mathrm{U} / \mathrm{Pb}$ concordia diagram for a hornblende leucogranite from the Teixeira batholith (A) and for a porphyritic syenogranite from the Serra Redonda pluton (B; see localization on Figs. 3 and 5). The discordant data represented by unshaded ellipses were not included in the concordia age calculations. For the diagrams, the data-point error ellipses are plotted with $1 \sigma$ errors.

cluster near the Concordia curve, with just one older, probably inherited grain (spot \#4), with a relatively high ${ }^{206} * \mathrm{~Pb} /{ }^{238} \mathrm{~Pb}$ ratio. A weighted ${ }^{206} * / \mathrm{Pb} /{ }^{238} \mathrm{~Pb}$ mean date for fifteen zircons, after excluding three discordant analyses (spots \#4, \#17, \#18), yielded an age of $575.4 \pm 2.1 \mathrm{Ma}(\mathrm{MSWD}=1.45$; probability $=0.12$ ). This age is indistinguishable from the Concordia age of $576 \pm 3.1 \mathrm{Ma}$ calculated without spots \#4 and \#18 (Fig. 7).

\section{Anisotropy of magnetic susceptibility of the Teixeira batholith}

\subsection{Sampling and AMS determination}

AMS was applied only in the Teixeira batholith as its massive, equigranular microstructure made it extremely difficult to determine its magmatic fabric using standard field measurements. The technique consists of measuring the magnetic susceptibility $(k)$ of a rock in different directions and defining the magnitude (intensity and orientation) of the three principal axes $k_{1} \geq k_{2} \geq k_{3}$. We measured the AMS of 554 specimens from 129 sites from the Mãe D'Água pluton to the Itapetim shear zone (Fig. 8). Some regions to the west and south of Mãe D'Água were not sampled due to problems with access. In Mãe D'Água, Jabre and Teixeira, we studied 49 (12 sites), 108 (33 sites) and 172 (36 sites) specimens, respectively. In the São Sebastião domain, which includes the aegirine-augite quartz syenite, we studied a total of 225 specimens (48 sites) of which 55 (14 sites) were of the quartz syenite. Included in the São Sebastião domain are 24 specimens (6 sites) just to the east of the Itapetim shear zone. At each site, we extracted two or three cylindrical cores nearly $7 \mathrm{~cm}$ of length and $2.5 \mathrm{~cm}$ of diameter with a portable gasoline-powered rock drill. The cores were oriented in place with a magnetic compass. In the laboratory, each cylindrical core was cut to produce two 2.2-cm-long specimens, so the AMS parameters (tensor magnitudes and directions) of each site are characterized by four to five specimens. Low-field AMS was measured in a KLY-2 Kappabridge device (AGICO) in the Laboratorio de Propriedades Físicas de Materiais Geológicos (Natal, UFRN). Specimen susceptibility and its normalized tensor principal directions were calculated using the Jelinek (1981) protocol.

Table 2 shows the average-site AMS parameters ( $K_{1} \geq K_{2} \geq K_{3}$ ) of the batholith (small caps symbols designate AMS specimen parameters). The symmetry of the magnetic fabric is represented by the $\mathrm{T}$ factor expressed by $\mathrm{T}=\left[2\left(\ln K_{2}-\ln K_{3}\right) /\left(\ln K_{1}-\ln K_{3}\right]-1 . \quad \mathrm{T}=-1 \quad\right.$ are for prolate ellipsoids $\left(K_{1}>K_{2}=K_{3}\right)$ and $\mathrm{T}=1$ are for oblate ellipsoids $\left(K_{1}=K_{2}>K_{3}\right)$. Neutral or triaxial ellipsoids have $\mathrm{T}=0\left(K_{1}>K_{2}>K_{3}\right)$. The degree of anisotropy is indicated by $\mathrm{P}=K_{1} / K_{3}$, which ranges from one (isotropic) to higher values.

\subsection{Low-field magnetic susceptibility data}

The magnetic susceptibility $(k)$ of the porphyritic granite of Mãe D’Água (0.11 mSI, st.dev., 0.02) and the aegirine-augite quartz syenite $(6.22$, st.dev, 5.92) shows a dominant unimodal distribution, while the Jabre, Teixeira and São Sebastião domains have a bimodal distribution (Fig. 9). The contrasting values of $\mathrm{k}$ in the porphyritic and aegirine-augite quartz syenite are typical of the paramagnetic and ferromagnetic granite series, respectively (Ishihara, 1977). The dominant ferromagnetic mineral in granites is usually magnetite, while in the paramagnetic granites most of the susceptibility contribution comes from $\mathrm{Fe} / \mathrm{Mg}$ silicates. This agrees with the rock content of opaque grains in the Teixeira batholith, absent in thin sections of the Mãe D'Água porphyritic granite and common in the aegirine-augite quartz syenite. $k$ shows a bimodal distribution in the equigranular granites of Jabre, Teixeira and São Sebastião, peaking between 0.10 and $0.30 \mathrm{mSI}$ and between $>1$ and $10 \mathrm{mSI}$. The highest $k$ values occur when opaque grains are visible in thin section. In addition, there is 


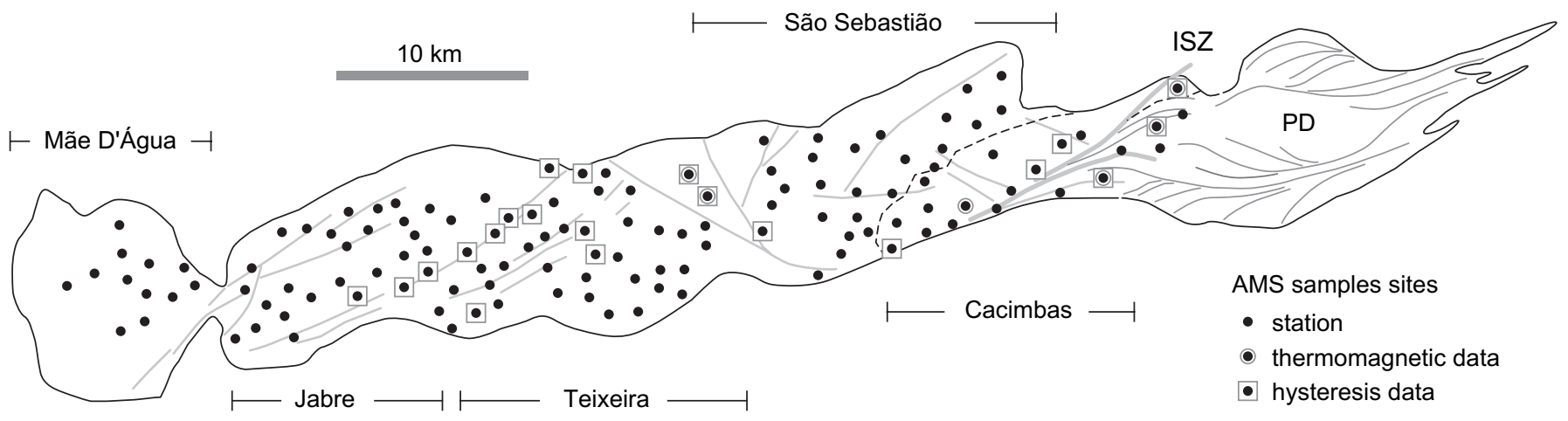

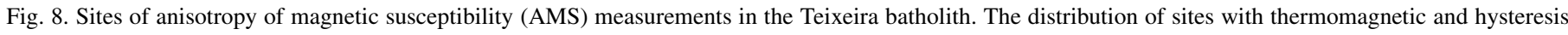

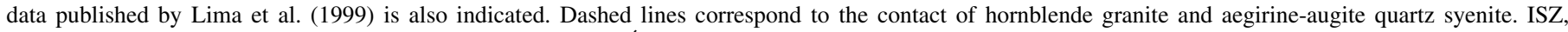

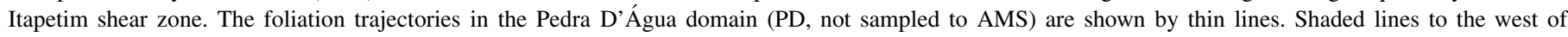
ISZ correspond to the main fracture and fault zones within the batholith.

a clear relation between $k>1 \mathrm{mSI}$ and the shear and fracture zones that crosscut the batholith (Fig. 9). $k<0.25 \mathrm{mSI}$ is typical in the Jabre and Teixeira domains and increases approaching the Tendó and Guaritas fracture zones. Close to the Itapetim shear zone, $k$ can reach values $>10 \mathrm{mSI}$. In the same way, the degree of anisotropy $\left(\mathrm{P}=k_{1} / k_{3}\right)$ increases to the east from the Mãe D’Água pluton $(\mathrm{P}=1.02$; st.dev. $0.01)$ to Jabre $(1.06 ; 0.03)$, Teixeira $(1.07 ; 0.06)$ and São Sebastião (1.08; 0.05) (Table 1); in the fracture and shear zones anisotropy reaches its highest magnitudes (1.11 to 1.13).

The magnetic mineralogy of the Teixeira batholith is detailed in Lima et al. (2000). Thermomagnetic data coupled with backscattered electron microscopy investigations show Ti-poor magnetite as the dominant ferromagnetic oxide. Hysteresis ratios of 19 specimens with a $k>0.35 \mathrm{mSI}$ plot on Day et al. (1977) plot on the right side of the pseudodomain field. Grains with this hysteresis ratio may correspond to mixtures of ferromagnetic particles with different susceptibilities and/or coercivity values (Dunlop, 2002). Mixtures of magnetite and hematite are probable candidates for the high remanent coercivity values of some specimens. Hematite was observed locally in small isolated grains or partially replacing magnetite (Lima et al., 2000). Results indicated that the regional variation of $\mathrm{k}$ and $\mathrm{P}$ depends mainly on the amount of magnetite, and is spatial related with the faulted and fractured zones within the batholith. The oxide contents as well the $k$ values decrease far from the deformed zones, suggesting a secondary origin for the magnetite and hematite grains.

\subsection{Magnetic fabric}

When we examine the magnetic lineations and foliations, two contrasting fabric styles become apparent. Foliations dip moderately to steeply $\left(>45^{\circ}\right.$; shaded area in Fig. 10) along the southern contact, close to the necked zone of Mãe D'Água, along the Itapetim shear zone and at the intersection of the Tendó and Guaritas fracture zones. The corresponding lineation plunges gently mostly to the east (mean lineation: 083,11). The magnetic fabric of the "batholith parallel" structures shows a different orientation. The magnetic foliation dips gently (Jabre and Teixeira) or moderately (Mãe D’Água, São Sebastião), while the lineation is transverse to the batholith elongation (mean lineation: 341,2). Furthermore, in the Jabre and Teixeira domains the foliation forms gentle basin- and dome-like structures, respectively. In São Sebastião, the magnetic fabric is nearly transverse to the batholith elongation, but approaching the Itapetim shear zone it progressively bends to become parallel to the stretching direction formed by the Itapetim and Taperoá shear zone system.

The transition of the magnetic fabric, especially the lineation, occurs from west to east along the batholith (Fig. 10). The Mãe D’Água pluton and Jabre-Teixeira domains show dominant NW- and N-trending lineations. Two sets of orthogonal lineations occur in the São Sebastião and Cacimbas domains and foliation rotates from NW-trending to E-trending approaching the Itapetim shear zone.

\subsection{Significance of magnetic fabric}

The relation between magnetic and mineral fabric directions in two cross-sections where they are highly discordant to the batholith elongation were studied by image analysis. 3-D mineral shape preferred orientation (SPO) was determined by combining fabric data from three mutually orthogonal 2-D rock sections (Robin, 2002), and the results were compared to AMS. Implementations and applications of this technique can be found in Launeau and Robin (2005).

The study of the preferred orientation of mafic minerals concerned five sites along the Jabre and four along Teixeira cross-sections (Fig. 11). Field oriented rock blocks of c. $10 \mathrm{~cm}$ dimensions and small quarries mined for pavement and local home constructions were used. The blocks were cut into three perpendicular sections and each face carefully oriented. After cleaning each block section or quarry face, high-resolution digital images were taken and later transferred to a microcomputer for treatment and mineral classification. Dark minerals are readily isolated from the leucocratic quartz-feldspar by threshold. The resulting binary image is improved by smoothing filters, which remove misclassified pixels 
Table 2

Anisotropy of magnetic susceptibility parameters of the Teixeira batholith

\begin{tabular}{|c|c|c|c|c|c|}
\hline Site & $K_{\mathrm{m}}(\mathrm{mSI})$ & $\mathrm{P}$ & $\mathrm{T}$ & $K_{1}$ & $K_{3}$ \\
\hline \multicolumn{6}{|c|}{ Мãe D'Água } \\
\hline 10 & 0.010 & 1.021 & 0.68 & $315,42(25.6)$ & $073,27(14.4)$ \\
\hline 11 & 0.140 & 1.013 & -0.31 & $209,2(21.1)$ & $117,37(28.0)$ \\
\hline 127 & 0.112 & 1.023 & -0.05 & 320,9 (14.6) & $210,6(63.6)$ \\
\hline 128 & 0.112 & 1.021 & 0.39 & 145,1 (33.2) & $057,28(11.8)$ \\
\hline 129 & 0.100 & 1.015 & 0.17 & $327,6(11.5)$ & $064,68(14.4)$ \\
\hline 130 & 0.093 & 1.027 & 0.05 & $329,7(20.4)$ & $158,82(18.5)$ \\
\hline 131 & 0.091 & 1.017 & -0.13 & 151,5 (18.9) & $050,62(39.9)$ \\
\hline 132 & 0.114 & 1.014 & -0.38 & $263,34(60.1)$ & $352,32(43.5)$ \\
\hline 133 & 0.090 & 1.016 & -0.48 & 336,7 (22.4) & $104,77(20.9)$ \\
\hline 134 & 0.084 & 1.033 & 0.25 & $326,2(32.0)$ & $064,45(26.5)$ \\
\hline 137 & 0.095 & 1.020 & -0.17 & $332,5(16.2)$ & $066,41(15.3)$ \\
\hline 138 & 0.092 & 1.017 & 0.23 & $178,6(60.6)$ & $071,48(35.9)$ \\
\hline \multicolumn{6}{|c|}{ Jabre } \\
\hline 01 & 0.391 & 1.080 & -0.45 & 053,8 (23.4) & $138,14(45.6)$ \\
\hline 31 & 0.157 & 1.035 & 0.39 & $001,7(24.0)$ & $102,55(7.5)$ \\
\hline 38 & 0.153 & 1.031 & 0.82 & $346,25(48.7)$ & $139,56(21.8)$ \\
\hline 39 & 0.138 & 1.041 & 0.98 & $117,6(49.7)$ & $354,79(3.4)$ \\
\hline 40 & 0.087 & 1.049 & 0.42 & $005,12(16.8)$ & $270,79(3.4)$ \\
\hline 42 & 0.156 & 1.048 & 0.50 & $341,9(10.3)$ & $160,81(10.8)$ \\
\hline 43 & 0.900 & 1.067 & -0.19 & $098,8(23.4)$ & $002,36(45.3)$ \\
\hline 44 & 0.140 & 1.033 & 0.59 & $115,6(25.5)$ & $306,86(14.5)$ \\
\hline 45 & 0.146 & 1.042 & 0.38 & $174,8(10.8)$ & $294,73(7.1)$ \\
\hline 47 & 0.130 & 1.051 & 0.64 & $340,18(7.7)$ & $119,67(3.2)$ \\
\hline 53 & 1.852 & 1.078 & 0.40 & $250,1(21.9)$ & $155,70(6.7)$ \\
\hline 54 & 0.129 & 1.041 & 0.65 & $003,4(23.2)$ & $113,77(4.6)$ \\
\hline 55 & 0.133 & 1.046 & 0.37 & $358,21(12.8)$ & $167,69(8.5)$ \\
\hline 56 & 0.116 & 1.039 & 0.76 & $307,14(54.5)$ & $170,75(24.3)$ \\
\hline 60 & 1.480 & 1.048 & 0.17 & $002,32(39.8)$ & $247,37(34.2)$ \\
\hline 61 & 1.099 & 1.091 & 0.62 & $194,1(33.2)$ & $094,84(5.4)$ \\
\hline 62 & 0.167 & 1.038 & 0.55 & $171,12(24.9)$ & $032,74(11.1)$ \\
\hline 63 & 0.120 & 1.035 & 0.71 & $191,9(12.4)$ & $019,81(4.2)$ \\
\hline 64 & 0.121 & 1.050 & 0.67 & $185,5(10.8)$ & $071,78(2.3)$ \\
\hline 65 & 0.116 & 1.043 & 0.92 & 232,5 (55.9) & $334,70(4.7)$ \\
\hline 66 & 0.121 & 1.042 & 0.55 & $207,2(16.8)$ & $110,75(9.3)$ \\
\hline 67 & 0.135 & 1.037 & 0.74 & $248,7(25.1)$ & $090,82(4.0)$ \\
\hline 68 & 0.735 & 1.111 & 0.71 & $175,8(40.2)$ & 271,35 (18.6) \\
\hline 69 & 2.629 & 1.071 & 0.49 & $106,22(51.9)$ & $310,58(40.4)$ \\
\hline 70 & 0.131 & 1.055 & 0.67 & $348,10(7.3)$ & $114,74(3.7)$ \\
\hline 71 & 0.142 & 1.041 & 0.43 & $182,0(9.1)$ & $294,89(8.3)$ \\
\hline 72 & 5.258 & 1.038 & -0.19 & $069,9(9.9)$ & $331,42(8.5)$ \\
\hline \multicolumn{6}{|c|}{ Teixeira } \\
\hline 02 & 0.697 & 1.143 & 0.11 & $085,45(7.0)$ & $335,22(13.2)$ \\
\hline 03 & 0.155 & 1.023 & 0.23 & $184,21(14.8)$ & $304,53(14.2)$ \\
\hline 04 & 0.096 & 1.054 & 0.19 & $024,17(32.2)$ & $130,6(46.3)$ \\
\hline 05 & 0.192 & 1.039 & 0.19 & $170,10(6.5)$ & $285,67(3.8)$ \\
\hline 06 & 0.130 & 1.051 & 0.16 & $154,2(11.1)$ & $248,63(9.7)$ \\
\hline 07 & 0.170 & 1.051 & 0.13 & $164,14(7.7)$ & $333,76(8.0)$ \\
\hline 08 & 0.102 & 1.035 & 0.81 & $178,2(27.6)$ & 279,77 (12.4) \\
\hline 09 & 1.269 & 1.027 & -0.38 & $297,0(23.3)$ & $032,8(34.2)$ \\
\hline 12 & 0.145 & 1.039 & 0.39 & $157,20(18.7)$ & $344,70(2.9)$ \\
\hline 13 & 0.150 & 1.030 & 0.35 & $190,13(34.7)$ & $013,79(15.5)$ \\
\hline 14 & 1.037 & 1.048 & -0.17 & $065,33(16.1)$ & $174,28(33.2)$ \\
\hline 15 & 0.102 & 1.026 & 0.46 & $058,44(25.7)$ & $291,29(12.9)$ \\
\hline 16 & 0.067 & 1.027 & -0.20 & $078,42(14.2)$ & $338,12(17.4)$ \\
\hline 17 & 0.135 & 1.029 & -0.21 & $085,30(17.5)$ & $359,12(17.9)$ \\
\hline 18 & 0.117 & 1.019 & 0.36 & $199,10(59.8)$ & $335,43(50.1)$ \\
\hline 19 & 0.133 & 1.032 & -0.03 & $080,12(12.9)$ & $175,19(9.3)$ \\
\hline 20 & 0.064 & 1.030 & 0.58 & 060,53 (28.6) & $179,18(6.4)$ \\
\hline 21 & 0.022 & 1.056 & -0.56 & $080,12(10.0)$ & $173,10(15.8)$ \\
\hline 22 & 0.083 & 1.033 & 0.50 & 146,7 (39.2) & $029,74(12.2)$ \\
\hline
\end{tabular}


Table 2 (continued)

\begin{tabular}{|c|c|c|c|c|c|}
\hline Site & $K_{\mathrm{m}}(\mathrm{mSI})$ & $\mathrm{P}$ & $\mathrm{T}$ & $K_{1}$ & $K_{3}$ \\
\hline 23 & 0.184 & 1.069 & -0.43 & $176,16(15.0)$ & $068,44(44.1)$ \\
\hline 24 & 0.375 & 1.102 & 0.57 & $124,2(12.7)$ & $022,81(5.5)$ \\
\hline 25 & 0.997 & 1.148 & 0.55 & $218,6(23.2)$ & $015,82(10.0)$ \\
\hline 26 & 0.157 & 1.043 & 0.15 & $150,6(5.1)$ & $253,66(6.1)$ \\
\hline 27 & 0.138 & 1.028 & 0.59 & $333,0(18.3)$ & $062,73(5.1)$ \\
\hline 28 & 0.062 & 1.064 & 0.23 & $268,4(12.4)$ & $360,7(6.3)$ \\
\hline 29 & 1.766 & 1.089 & -0.23 & $220,10(9.3)$ & 048,80 (9.6) \\
\hline 30 & 2.025 & 1.156 & 0.23 & $239,3(35.3)$ & 332,74 (18.7) \\
\hline 32 & 0.173 & 1.059 & 0.59 & $334,22(9.3)$ & $209,55(6.1)$ \\
\hline 33 & 0.925 & 1.104 & 0.90 & $158,1(64.2)$ & $255,86(6.3)$ \\
\hline 34 & 0.304 & 1.057 & 0.11 & $340,29(12.7)$ & $185,56(13.1)$ \\
\hline 35 & 1.675 & 1.090 & 0.62 & $020,2(20.8)$ & $261,88(18.2)$ \\
\hline 36 & 0.132 & 1.022 & 0.29 & $115,18(26.1)$ & 000,56 (18.4) \\
\hline 37 & 0.251 & 1.054 & 0.53 & $033,1(26.0)$ & $125,74(14.3)$ \\
\hline 41 & 0.083 & 1.016 & 0.57 & $098,17(7.2)$ & $193,17(41.5)$ \\
\hline 46 & 0.149 & 1.045 & 0.25 & $341,19(36.4)$ & $116,62(22.8)$ \\
\hline 48 & 0.662 & 1.189 & 0.56 & $087,25(29.9)$ & $221,55(8.4)$ \\
\hline 49 & 0.121 & 1.066 & 0.85 & $057,35(31.8)$ & $240,53(16.3)$ \\
\hline 50 & 0.121 & 1.061 & 0.83 & $120,19(29.3)$ & $250,64(7.0)$ \\
\hline 51 & 0.127 & 1.066 & 0.65 & $100,39(11.7)$ & $267,50(5.2)$ \\
\hline 52 & 0.747 & 1.070 & -0.21 & $035,22(14.8)$ & $296,18(18.8)$ \\
\hline 73 & 0.292 & 1.066 & 0.39 & $135,49(35.8)$ & $276,36(9.7)$ \\
\hline 74 & 1.363 & 1.188 & 0.75 & $119,16(18.3)$ & $232,52(6.6)$ \\
\hline 75 & 0.083 & 1.082 & 0.32 & $185,2(17.1)$ & $282,66(10.7)$ \\
\hline \multicolumn{6}{|c|}{ São Sebastião } \\
\hline 57 & 0.103 & 1.049 & 0.74 & $353,7(24.7)$ & $210,82(5.2)$ \\
\hline 58 & 0.156 & 1.049 & 0.54 & $358,30(17.9)$ & $227,48(8.2)$ \\
\hline 59 & 1.557 & 1.064 & -0.06 & $358,16(41.8)$ & $136,70(43.0)$ \\
\hline 76 & 4.121 & 1.092 & 0.32 & $007,30(22.0)$ & $246,42(12.0)$ \\
\hline 77 & 6.687 & 1.108 & 0.11 & $021,33(9.5)$ & 250,45 (11.7) \\
\hline 78 & 0.109 & 1.029 & -0.07 & $123,26(8.4)$ & $270,60(13.4)$ \\
\hline 79 & 0.100 & 1.042 & 0.32 & $342,37(10.9)$ & $209,44(21.5)$ \\
\hline 80 & 0.121 & 1.039 & 0.22 & $342,40(6.6)$ & 210,39 (15.5) \\
\hline 81 & 0.127 & 1.071 & 0.73 & $359,15(9.4)$ & 232,66 (4.9) \\
\hline 82 & 1.200 & 1.143 & 0.01 & $261,25(31.2)$ & 359,13 (23.6) \\
\hline 83 & 7.742 & 1.080 & 0.52 & $127,5(8.9)$ & $225,56(13.1)$ \\
\hline 84 & 0.122 & 1.092 & 0.74 & $341,27(24.1)$ & $203,57(8.8)$ \\
\hline 85 & 0.129 & 1.058 & 0.63 & $002,31(25.7)$ & 235,45 (4.2) \\
\hline 86 & 3.806 & 1.110 & 0.08 & $243,10(24.8)$ & $331,3(15.3)$ \\
\hline 87 & 1.305 & 1.017 & -0.82 & 294,17 (31.6) & $029,26(59.5)$ \\
\hline 88 & 8.640 & 1.162 & 0.15 & $134,1(12.4)$ & 229,67 (11.0) \\
\hline 89 & 2.653 & 1.181 & -0.04 & $299.18(15.2)$ & 197,35 (11.6) \\
\hline 90 & 10.610 & 1.053 & 0.20 & $323,16(11.0)$ & $206,56(10.2)$ \\
\hline 97 & 0.179 & 1.030 & 0.11 & $358,23(15.2)$ & $252,36(18.8)$ \\
\hline 98 & 0.133 & 1.112 & 0.41 & $354,15(10.0)$ & $234,62(6.8)$ \\
\hline 99 & 4.633 & 1.095 & 0.74 & $137,13(9.0)$ & $268,70(7.0)$ \\
\hline 100 & 13.853 & 1.125 & 0.39 & $134,6(6.6)$ & $237,64(4.8)$ \\
\hline 101 & 0.186 & 1.040 & -0.29 & $167,16(16.5)$ & $062,42(24.8)$ \\
\hline 102 & 0.565 & 1.026 & 0.49 & $110,13(28.9)$ & $002,73(25.2)$ \\
\hline 103 & 0.627 & 1.048 & 0.32 & $162,24(30.6)$ & 347,66 (30.8) \\
\hline 104 & 8.027 & 1.079 & 0.70 & 130,17 (7.4) & $297,72(7.0)$ \\
\hline 105 & 3.721 & 1.062 & -0.53 & $358,14(39.7)$ & 193,66 (51.6) \\
\hline 114 & 1.305 & 1.066 & 0.15 & $321,30(13.2)$ & $188,48(7.8)$ \\
\hline 115 & 0.161 & 1.019 & 0.24 & $076,36(35.4)$ & 231,55 (30.6) \\
\hline 116 & 2.072 & 1.063 & 0.92 & $234,14(52.4)$ & $025,74(12.0)$ \\
\hline 117 & 1.877 & 1.233 & -0.44 & $100,2(18.1)$ & $012,64(28.0)$ \\
\hline 118 & 2.902 & 1.034 & -0.41 & $286,66(45.1)$ & $080,50(45.5)$ \\
\hline 119 & 0.226 & 1.062 & 0.76 & $336,30(39.4)$ & $181,53(24.7)$ \\
\hline 120 & 12.551 & 1.164 & -0.45 & $172,27(4.0)$ & 032,57 (42.0) \\
\hline 121 & 0.445 & 1.058 & 0.02 & $190,58(12.1)$ & $359,31(6.4)$ \\
\hline 125 & 0.578 & 1.056 & -0.03 & $263,24(37.4)$ & 024,42 (32.6) \\
\hline 126 & 2.639 & 1.069 & 0.17 & $241,6(12.9)$ & 336,28 (16.7) \\
\hline 135 & 0.120 & 1.050 & 0.79 & $332,15(33.3)$ & $225,44(10.5)$ \\
\hline
\end{tabular}


Table 2 (continued)

\begin{tabular}{|c|c|c|c|c|c|}
\hline Site & $K_{\mathrm{m}}(\mathrm{mSI})$ & $\mathrm{P}$ & $\mathrm{T}$ & $K_{1}$ & $K_{3}$ \\
\hline 136 & 0.137 & 1.069 & 0.64 & $340,8(18.8)$ & $239,50(13.4)$ \\
\hline \multicolumn{6}{|c|}{ Cacimbas } \\
\hline 92 & 4.063 & 1.071 & 0.17 & $104,14(2.6)$ & $000,44(9.6)$ \\
\hline 93 & 13.443 & 1.310 & 0.03 & $078,14(4.2)$ & $335,42(2.1)$ \\
\hline 94 & 0.336 & 1.086 & 0.09 & $255,5(9.0)$ & $350,51(12.0)$ \\
\hline 106 & 6.685 & 1.056 & -0.13 & 074,1 (17.9) & $164,22(28.6)$ \\
\hline 107 & 16.465 & 1.138 & 0.06 & 283,15 (11.4) & $178,45(4.0)$ \\
\hline 108 & 2.125 & 1.306 & -0.03 & $260,15(6.1)$ & $160,34(5.0)$ \\
\hline 109 & 4.227 & 1.099 & 0.54 & $086,23(3.4)$ & $343,29(6.0)$ \\
\hline 110 & 0.893 & 1.040 & -0.18 & $090,41(32.6)$ & $203,18(31.8)$ \\
\hline 111 & 8.655 & 1.076 & -0.33 & $288,2(11.2)$ & $018,4(26.8)$ \\
\hline 124 & 0.102 & 1.060 & 0.46 & 069,4 (19.4) & $336,28(12.9)$ \\
\hline
\end{tabular}

$K_{\mathrm{m}}$, mean-site susceptibility $\left(10^{-1} \mathrm{SI}\right)$; P, degree of anisotropy; T, shape parameter; $K_{1}$ and $K_{3}$, respectively, mean-site maximum and minimum susceptibility directions (azimuth and dip). In parentheses the angular dispersion (1.5-sigma) about the AMS principal directions is given.

such as isolated pixels or one-pixel-thick lines and shapes of $<32$ pixels.

The binary images consist of mafic minerals in a blank background, and were analyzed using the Intercept Method (Launeau and Robin, 1996), which provides a record of the orientation distribution of the boundaries of the mafic phase. The individual image is then divided into four sub-images and, on each subset, the orientation distribution of the boundaries described by a 2-D shape tensor. The resulting shape tensors of the three perpendicular faces from a single block or quarry are then combined in $3^{4}$ different ways to reconstruct a 3-D shape ellipsoid. A confidence cone $(1.5 \sigma)$ encloses the principal directions $(\mathrm{A}>\mathrm{B}>\mathrm{C})$ of 64 ellipsoids calculated after dividing each "full" image in four sub-images
(Fig. 11). Solid symbols are for the "bulk" ellipsoid found by combining SPO parameters of each full image (single set, combination $3^{1}$ ). If the tensor principal directions of the "bulk" ellipsoid fall inside the $1.5 \sigma$ cone interval, the counting window data are considered enough and the fitted ellipsoid has high bulk compatibility. Moreover, a "compatibility index" between the sought ellipsoid and the respective sectional ellipses is given by the $\sqrt{ } \mathrm{F}$ parameter. The ellipsoid fit is considered well defined for $\sqrt{ } \mathrm{F}=0 \%$ and poorly defined when $\sqrt{ } \mathrm{F}>10 \%$ (Robin, 2002; Launeau and Robin, 2005).

\subsubsection{Results}

The SPO parameters of the 3-D distribution of the mafic phase for the Jabre and Teixeira cross-sections are summarized
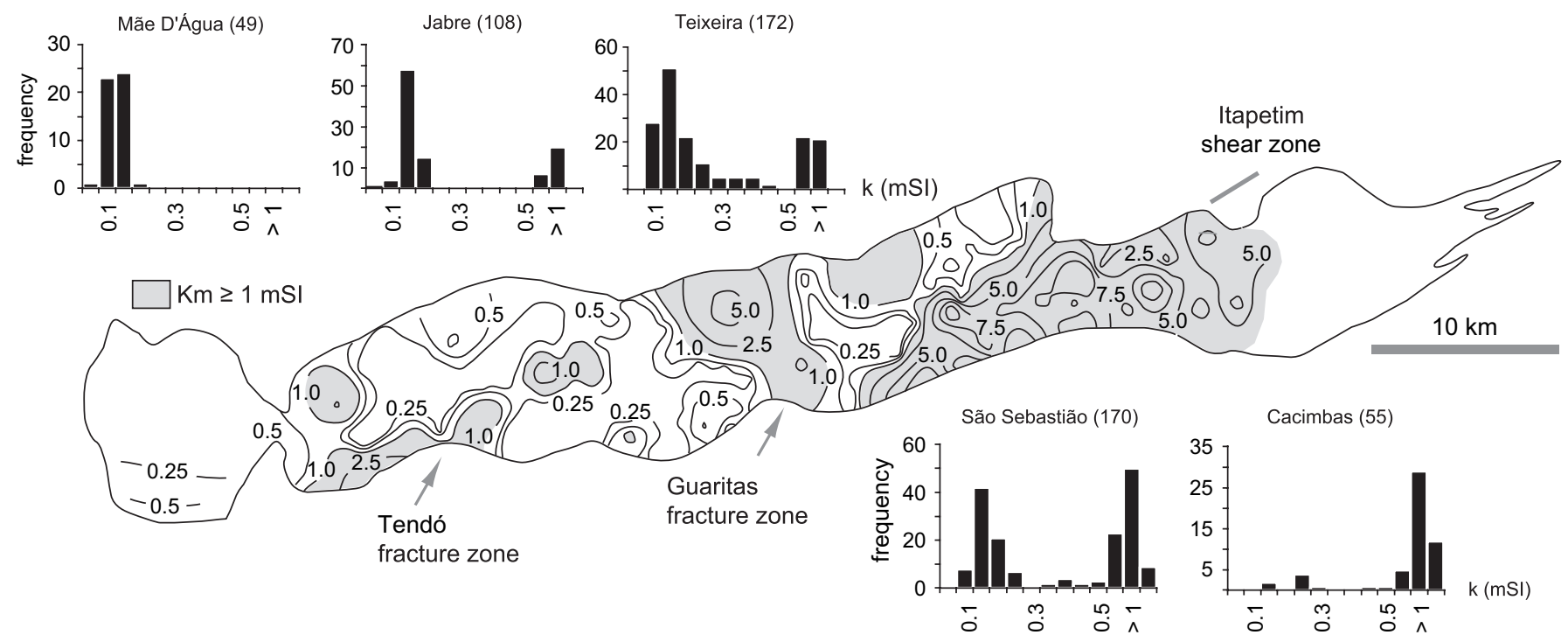

Fig. 9. Magnetic susceptibility of the Teixeira batholith. The frequency histograms correspond to the different domains of the batholith (see text). 


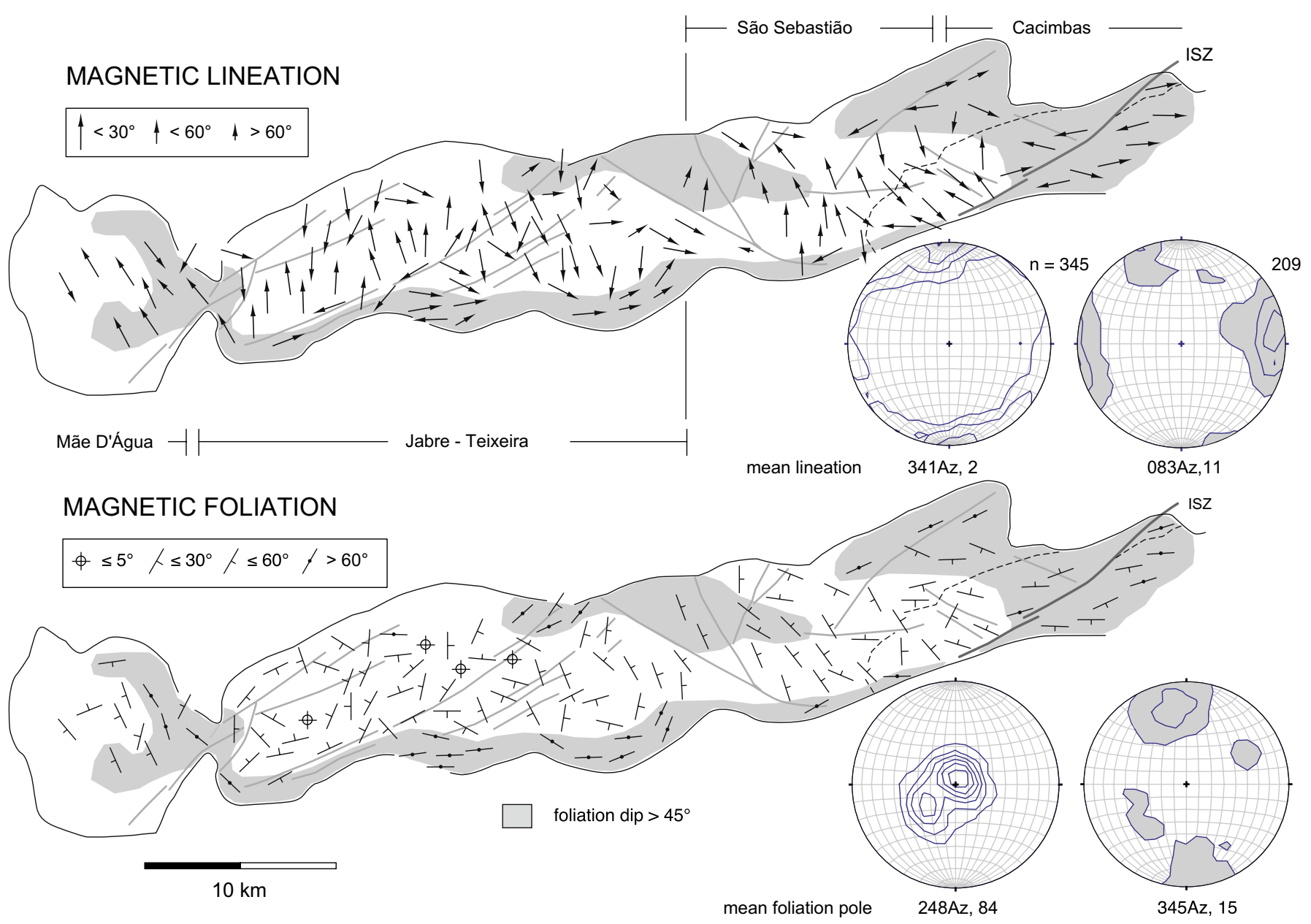

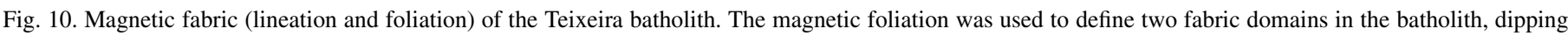

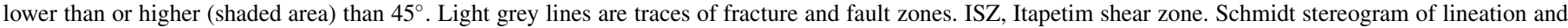
the foliation poles, lower hemisphere (contours of $2 \%, 4 \%, \ldots 12 \%$ per $1 \%$ area).

in Table 3. The calculated ellipsoid fits well with the sectional ellipses as indicated by low $\sqrt{\mathrm{F}}$ values, typically below $3.0 \%$, with $6.2 \%$ in one site (PG). The ellipsoid shape ratio (SR) varies between 1.14 and 1.20 in the Jabre cross-section but reaches 1.41 in the Teixeira cross-section. SPO anisotropies are much higher than magnetic anisotropies (Table 2), indicating that the mafic fabric is better defined than AMS. The ellipsoid shape changes for both cross-sections, typically oblate in the Jabre and prolate in the Teixeira cross-section.

In the Jabre cross-section, the shape foliation (normal to the short axis, C) is subhorizontal (\#70, \#60), although approaching the southern granite contact, it dips moderately to northwest (\#50, \#40). At one site the foliation dips steeply to the west (\#80). Along the cross-section, the shape lineation (parallel to long axis A) remains transversal or highly oblique to the pluton elongation. In the Teixeira cross-section, the foliation varies while the lineation maintains a consistent orientation approximately at a high angle to the pluton elongation.

This study shows that AMS and mafic mineral fabrics have similar orientations in both cross-sections. Dominant prolate or oblate ellipsoids are found in the Teixeira and Jabre cross-sections, respectively. In the former, the prolate mafic fabric is attributed to amphibole prisms that describe the mineral preferred orientation. An inversion of $\mathrm{B}$ and $\mathrm{C}$ principal axes occurs at one site (PG) with a moderate prolate shape $(\mathrm{T}=-0.49)$. Biotite and amphibole outline the mafic fabric of the Jabre cross-section. Only at one site (\#80) is the dip of the mineral foliation significantly higher than the magnetic foliation, although its respective lineations remain similar. At the remaining sites of the Jabre cross-section, AMS and mineral fabric are nearly coaxial.

\section{Discussion}

Image analysis to compare magnetic and mineral fabrics supports the use of AMS to describe the orientation of the magmatic fabric of the Teixeira batholith. The orientation varies from highly discordant in its central and western domains to concordant when the fabric becomes gneissic and magnetite is crystallized. We postulate that the discordant magmatic fabric corresponds to emplacement structures formed before the strike-slip shearing related to the PatosItapetim-Taperoá shear zone system. Thus, the Teixeira would be a pre-transcurrent batholith. The Serra Redonda 


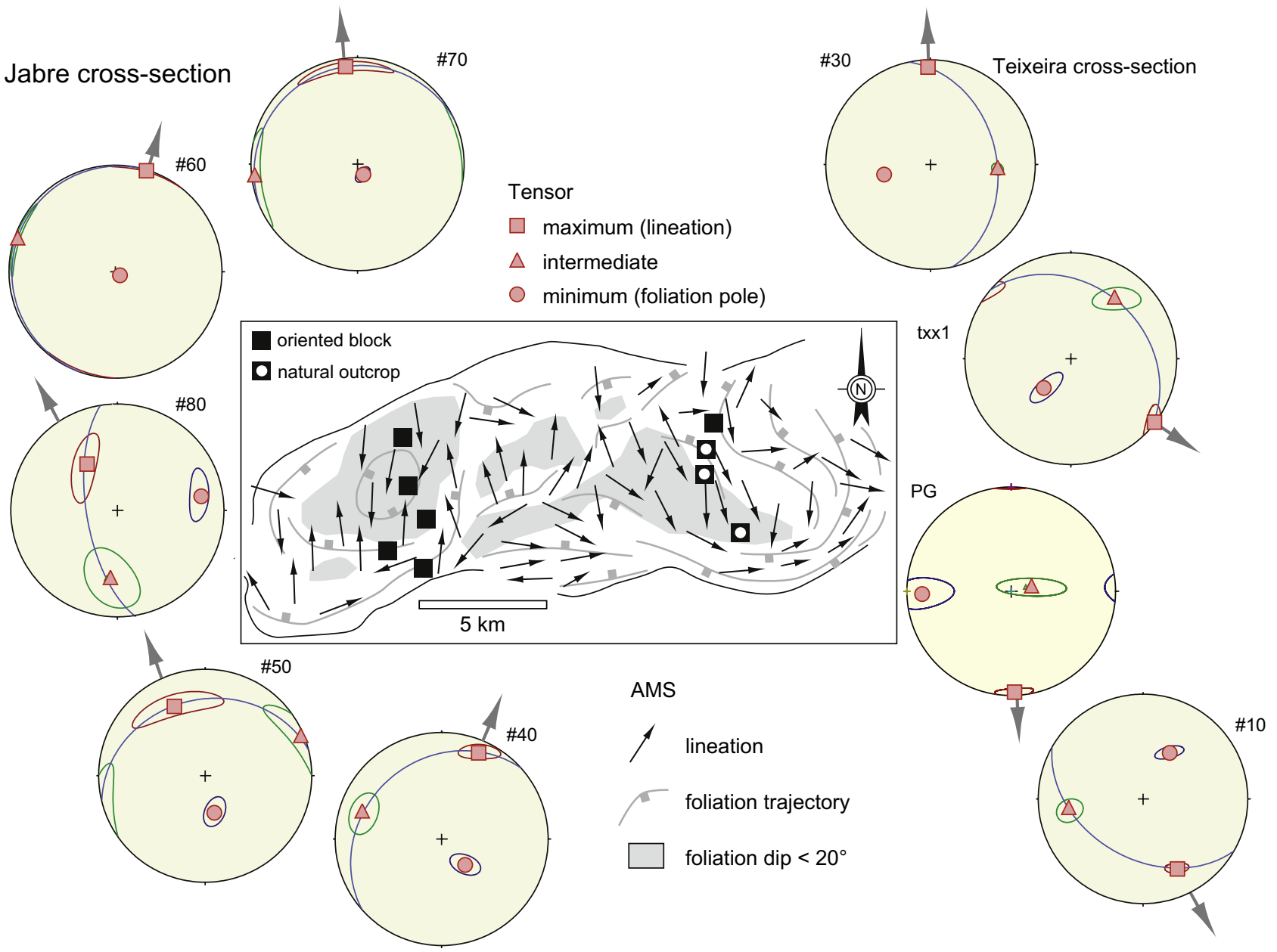

Fig. 11. Shape preferred orientation of mafic mineral in cross sections of the Jabre and Teixeira domains. Solid symbols are for the "full ellipsoid", i.e. that described by the tensor principal directions resulting from the combination of all data on each of the three mutually orthogonal sections. The cone projections $(1.5 \sigma)$ enclose the distribution of $64\left(=4^{3}\right)$ "subset ellipsoids" found after dividing the counting windows in four sub-images and combining them in each section (cf. Launeau and Robin, 2005). Arrow points the mean direction of the mineral lineation. Schmidt stereogram, lower hemisphere.

pluton, on the other hand, shows fabric orientations consistent with the host regional strain field, and is considered syntectonic.

Internal discordant or concordant fabrics in the Teixeira batholith are related to the external wall-rock structure. There are steeply dipping foliations parallel to the batholith margins with subhorizontal $\left(\mathrm{D}_{1}\right)$ or, particularly along its northern margin, steeply plunging $\left(D_{2}\right)$ lineations. Both $D_{1}$ and $D_{2}$ structures are attributed to a transpressive regional deformation that combined simple shear and a bulk N- to NW-shortening. The vergence of asymmetric $D_{2}$ folds formed during rightlateral movement of the Patos shear zone, squeezing and displacing "soft" metasediments against the "hard" hanging-wall (batholith). This implies that the batholith was entirely crystallized when the shear zone system was active, as illustrated in the Pedra D'Água domain (Fig. 4). There, the connection between Patos, Itapetim and Taperoá shear zones develops a typical asymmetric extensional structure, with the Itapetim and Taperoá branches corresponding to the NE-trending shear band components, while the E-trending Patos branch corresponds to the C-plane shear component. The shear bands turn progressively to merge further north with the Patos mylonites. The sigma-shaped sheets of Pedra D'Água granite between the Itapetim and Taperoá shear zones are entirely foliated with a fabric similar to the host orthogneisses. Shear deformation decreases towards the São Sebastião, Teixeira and Jabre domains as shortening is accommodated by a set of conjugate fractures and fault zones. Locally, as in the Tendó fracture zone, a strong comminution of the equigranular granite forms narrow and discontinuous bands of mylonite and ultramylonite together with intense fracturing. Far from these domains, however, the granite fabric is medium-grained equigranular.

A magmatic fabric predating shear zone deformation occurs in the inner parts of the Teixeira batholith. AMS is characterized by gently dipping foliations locally forming basin (Jabre) and dome (Teixeira) structures, and by lineations trending N- or NW (Figs. 10 and 11). Mean susceptibility values of $0.25 \mathrm{mSI}$ contrast with the "batholith-concordant" magnetic fabric, in which mean susceptibility is higher than $1 \mathrm{mSI}$. The "batholith-discordant" magnetic fabric would have been acquired during the magma crystallization at about 
Table 3

Shape preferred orientation of mafic minerals from cross sections in the Teixeira batholith determined by the Intercept Method

\begin{tabular}{|c|c|c|c|c|c|c|}
\hline & SR & $\mathrm{T}$ & $\mathrm{vF}(\%)$ & A & B & $\mathrm{C}$ \\
\hline \multicolumn{7}{|c|}{ Jabre cross-section } \\
\hline \#70 & 1.18 & 0.54 & 1.7 & $352,09(21.6)$ & $262,03(21.6)$ & $154,81(5.2)$ \\
\hline \#60 & 1.20 & 0.62 & 0.9 & $019,00(16.3)$ & $289,03(16.3)$ & $109,87(1.7)$ \\
\hline \#80 & 1.14 & 0.35 & 1.9 & $323,47(20.8)$ & $185,34(20.6)$ & $079,23(13.3)$ \\
\hline \#50 & 1.15 & 0.29 & 2.0 & $338,28(24.2)$ & $069,03(23.9)$ & $165,61(9.0)$ \\
\hline$\# 40$ & 1.13 & -0.10 & 1.8 & $023,11(10.7)$ & $288,24(10.5)$ & $137,63(9.5)$ \\
\hline \multicolumn{7}{|c|}{ Teixeira cross-section } \\
\hline \#30 & 1.15 & 0.09 & 1.0 & $358,08(3.2)$ & $094,36(4.0)$ & $258,53(3.8)$ \\
\hline Txl & 1.30 & -0.26 & 3.1 & $128,02(10.1)$ & $037,29(14.3)$ & $220,60(12.4)$ \\
\hline PG & 1.23 & -0.49 & 1.0 & $159,06(2.6)$ & $040,78(13.4)$ & $250,11(13.4)$ \\
\hline \#10 & 1.16 & -0.32 & 1.1 & $154,27(6.4)$ & $261,30(9.2)$ & $029,48(8.8)$ \\
\hline
\end{tabular}

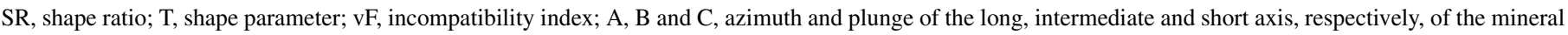
fabric, with the semi-angle (measured in degrees) of the 1.5-sigma ellipse of confidence around the mean axis given in parentheses.

$591 \pm 5 \mathrm{Ma}$. Although the shape of the batholith was later modified by strike-slip shearing, its dike-like aspect and emplacement along the contact between metasediments and orthogneisses of the Alto Pajeú belt appear to constitute primary features. In addition, it shows remarkably homogeneous composition and texture, with no evidence of internal sheeting, structures indicative of forceful emplacement, or hornfels at the contact with metapelites. If there was contact metamorphism, it was overprinted during the development of $\mathrm{D}_{1}$ and $\mathrm{D}_{2}$ events. Furthermore, subhorizontal fabrics found in the Jabre and Teixeira domains suggest that the present exposure level, at least in these domains, corresponds to the cupola of the intrusion. The occurrence of aegirine-augite and blue amphibole in the Cacimbas pluton places the Teixeira batholith in the peralkaline magmatic series, which includes syenite plutons and stocks, ring dikes and dike swarms (Ferreira et al., 1998).

The Serra Redonda pluton, on the other hand, shows magmatic fabrics coupled with the host rock strain. It includes thrusts and a conjugate strike-slip shear zone set consistent with bulk NNW-shortening, which also stretched the pluton parallel to the contact between the Paleoproterozoic basement and the Early Neoproterozoic rocks. Evidence for syntectonic emplacement also comes from diorite dikes that crosscut the thrust hanging-wall, and were deformed by the regional strain. Several processes could account for the observed patterns of strain variation within plutons emplaced in a contractional setting, such as local dilation created by syn-melting shear zone movement (D'Lemos et al., 1992), or dilation assisted by melt-enhanced embrittlement (Davidson et al., 1994). Recent numerical models predict the emplacement of magmas in a bulk transpressive setting if shear zones are localized at contacts between rocks with different rheological properties (Weinberg et al., 2004). The resulting strain field forms fragile, low-mean pressure traps into which melts can ascend to form a pluton. These syntectonic bodies generally form sheeted plutons. If the pluton exhibits little compositional variation, evidence of internal sheeting can only be identified by the presence of wall rock screens or inclusions along its contacts (Hutton, 1992). Although no wall-rock screens separate the magmatic units of the Serra Redonda pluton, the intrusion of the diorite at the pluton border parallel to the contact with the porphyritic granite is attributed to a sheeting mechanism. Its crystallization age of $576 \pm 3 \mathrm{Ma}$, obtained from zircons from a coarse porphyritic granite, is a good approximation for the age of the NNW-shortening that affected this domain of the province.

Tectonic fabrics in the Alto Pajeú belt record a bulk transpressive strain field: there are strongly foliated rocks, anastomosing less deformed $\mathrm{km}$-scale lenses, conjugate shear zones and belt-parallel subhorizontal stretching. Conjugate sets of shear bands indicating that the principal compressive stress is oriented at a high angle to the rocks flanking the shear zone have been described in several fault systems (Jones and Tanner, 1994; Pereira and Silva, 2004). These suggest that the transpressive strains were partitioned into a pure shear component stronger than the simple shear component. Conjugate structures along hundreds of kilometers south of the Patos shear zone lead us to postulate that the deformation of the Alto Pajeú belt includes a strong regional shortening component at a high angle to the belt margins. This component is attributed to far-field stresses resulting from the convergence of Paleoproterozoic cratons, especially the São Francisco to the south, which would have squeezed and laterally displaced the crustal blocks of eastern Borborema.

\section{Conclusion}

Magmatic fabric of the Teixeira batholith and the Serra Redonda pluton indicate they are, respectively, pre- and synkinematic regarding the Patos and its satellite shear zones. Evidence for the emplacement of the Teixeira batholith preceding the transcurrent deformation comes from AMS and structural data. Magnetic/magmatic fabrics transversal to the batholith elongation are found in granites with mean susceptibility values $\leq 0.25 \mathrm{mSI}$. They contrast with the orientation of the metamorphic fabric in the wall-rocks. Shear zones that branch off from Patos mylonites rework partially the magmatic fabric. Near the batholith margins and close to the fracture and fault zones the fabric changes its orientation to parallel to the body 
elongation. These secondary, post-emplacement fabrics occur in granitoids with susceptibility values $>1 \mathrm{mSI}$ related to the recrystallization of magnetite and, locally, hematite. The reactivation of magmatic and host rock metamorphic fabrics in the Teixeira batholith is attributed to E-trending shearing coupled to a bulk N- to NW compressive deformation. Similar strain regime controlled the emplacement of the Serra Redonda pluton. A concordant U/Pb Shrimp zircon age of $576 \pm 3$ Ma from a coarse porphyritic granite offers the best estimation for its syntectonic crystallization as well for the development of the regional transpression that reworked part of the Teixeira batholith.

The deformation of the Early Neoproterozoic Alto Pajeú belt country rocks, partitioned between sets of conjugated strike-slip shear zones and belt-perpendicular shortening, is attributed to the collisional tectonics related to the convergence of Paleoproterozoic cratons. The onset of the collision-related structures, focused on this study on the Patos and its satellite shear zones, must be younger than $591 \pm 5 \mathrm{Ma}$ as indicated by crystallization ages of the Teixeira batholith.

\section{Acknowledgments}

This work was supported by Fundação de Amparo a Pesquisa do Estado de São Paulo (grants 03/13023-7 and 04/ 08614-9), Conselho Nacional de Desenvolvimento Científico e Tecnológico (CNPq) and Pró-Reitoria de Pesquisa of São Paulo University. Elson Oliveira and Alain Vauchez through the pertinence of their reviews helped us to improve the paper.

\section{References}

Almeida, C.N., Guimarães, I.P., Silva Filho, A.F., 2002. Petrogênese de rochas félsicas e máficas na Província Borborema, NE do Brasil: o complexo cálcio-alcalino de alto-K de Campina Grande. Revista Brasileira de Geociências 32 (2), 205-216.

Archanjo, C.J., Trindade, R.I.F., Bouchez, J.L., Ernesto, M., 2002. Granite fabrics and regional-scale partitioning in the Seridó belt (Borborema Province, NE Brazil). Tectonics 21 (1), doi:10.1029/2000TC001269.

Archanjo, C.J., Fetter, A.H., 2004. Emplacement setting of the granite sheeted pluton of Esperança (Brasiliano orogen, Northeastern Brazil). Precambrian Research 135, 193-215.

Borradaile, G.J., Henry, B., 1997. Tectonic applications of magnetic susceptibility and its anisotropy. Earth Science Reviews 42 (1/2), 49-93.

Bouchez, J.L., 1997. Granite is never isotropic: an introduction to AMS studies of granitic rocks. In: Bouchez, J.L., Hutton, D.H.W., Stephens, W.E. (Eds.), Granite: From Segregation of Melt to Emplacement Fabrics. Kluwer Academic Publishers, pp. 95-112.

Bouchez, J.L., Delas, C., Gleizes, G., Nédélec, A., Cuney, M., 1992. Submagmatic microfractures in granites. Geology 20 (1), 35-38.

Brown, M., Solar, G.S., 1998. Granite ascent and emplacement during contractional deformation in convergent orogens. Journal of Structural Geology 20 (9/10), 1365-1393.

Brito Neves, B.B., Santos, E.J., Van Schmus, W.R., 2000. Tectonic history of the Borborema Province, northeastern Brazil. In: Cordani, U.G., Milani, E.J., Thomaz Filho, A., Campos, D.A. (Eds.), Tectonic Evolution of South America. Sociedade Brasileira de Geologia, Rio de Janeiro, pp. 151-182.

Brito Neves, B.B., Campos Neto, M.C., Van Schmus, W.R., Santos, E.J., 2001. O sistema Pajeú-Paraíba e o Maciço São José de Campestre no Leste da Borborema. Revista Brasileira de Geociências 31 (2), 173-184.
Corsini, M., Vauchez, A., Archanjo, C.J., Jardim de Sá, E.F., 1991. Strain transfer at continental scale from a transcurrent shear zone to a transpressional fold belt: the Patos-Seridó system, northeastern Brazil. Geology 19, 586-589.

Compston, W., Williams, I.S., Kirschvink, J.L., Zang, Z., Ma, G., 1992. Zircon $\mathrm{U} / \mathrm{Pb}$ ages for the Early Cambrian time scale. Journal of Geological Society, London 149, 171-184.

Davidson, C., Schmid, S.M., Hollister, L.S., 1994. Role of melt during deformation in the deep crust. Terra Nova 6, 133-142.

Davison, I., MacCarthy, M., 1995. Laminar flow in shear zones: the Pernambuco Shear Zone, NE-Brazil. Journal of Structural Geology 17, 149-161.

Day, R.M., Fuller, M., Schmidt, V.A., 1977. Hysteresis properties of titanomagnetites: grain size and composition dependence. Physics of the Earth and Planetary Interiors 13, 260-267.

D'Lemos, R.S., Brown, M., Strachan, R.A., 1992. Granite magma generation, ascent and emplacement within a transpressional orogen. Journal of Geological Society, London 149, 487-490.

Dunlop, D.J., 2002. Theory and application of the Day plot (Mrs/Ms versus $\mathrm{Hcr} / \mathrm{Hc}$ ) 2. Application to data for rocks, sediments and soils. Journal Geophysical Research 107 (B3), doi:10.1029/2001JB0000487.

Fetter, A.H., Santos, T.J.S., Van Schmus, W.R., Hackspacher, P.C., Brito Neves, B.B., Arthaud, M.H., Nogueira Neto, J.A., Wernick, E., 2003. Evidence for Neoproterozoic continental arc magmatism in the Santa Quitéria batholith of Ceará State, NW Borborema Province, NE Brazil: implications for the assembly of West Gondwane. Gondwana Research 6 (2), 265-273.

Ferreira, V.P., Sial, A.N., Jardim de Sá, E.F., 1998. Geochemical and isotopic signatures of Proterozoic granitoids in terranes of the Borborema structural province, northeastern Brazil. Journal of South American Earth Sciences $11,439-455$.

Guimarães, I.P., Silva Filho, A.F., Almeida, C.N., Van Schmus, W.R., Araújo, J.M.M., Melo, S.C., Melo, E.B., 2004. Brasiliano (Pan-African) granitic magmatism in the Pajeú-Paraíba belt, Northeast Brazil: an isotopic and geochronological approach. Precambrian Research 135, $23-53$.

Hutton, D.H.W., 1988. Granite emplacement mechanisms and the tectonic controls: inferences from deformation studies. Transactions of the Royal Society of Edinburgh: Earth Sciences 79, 245-255.

Hutton, D.H.W., 1992. Granite sheeted complexes: evidence for the dyking ascent mechanism. Transactions of the Royal Society of Edinburgh: Earth Sciences 83, 377-382.

Ishihara, S., 1977. The magnetite-series and ilmenite-series granitic rocks. Mining Geology 27, 293-305.

Jelinek, V., 1981. Characterization of the magnetic fabrics of rocks. Tectonophysics 79, 63-67.

Launeau, P., Robin, P.Y., 1996. Fabric analysis using the intercept method. Tectonophysics 267, 91-119.

Launeau, P., Robin, P.Y., 2005. Determination of fabric and strain ellipsoids from measured sectional ellipses-implementations and applications. Journal of Structural Geology 27, 2223-2233.

Lee, J.K.W., Tromp, J., 1995. Self-induced fracture generation in zircon. Journal of Geophysical Research, Solid Earth 100 (B9), 17753-17770.

Lima, R.G., Archanjo, C.J., Macedo, J.W.P., Melo Jr., G., 2000. Anomalias de suscetibilidade magnética no batólito granítico de Teixeira (Província da Borborema, Nordeste do Brasil) e sua relação com a zona de cisalhamento de Itapetim. Revista Brasileira de Geociências 30 (4), 685-692.

Ludwig, K.R., 2003. Isoplot 3.00: A Geochronological Toolkit for Microsoft Excel $^{\circledR}$ (revised version). In: Special Publication 4. Berkeley Geochronological Center, Berkeley, CA, $70 \mathrm{pp}$

Ludwig, K.R., 2000. SQUID 1.00. In: A User Manual, vol. 2. Berkeley Geochronology Center Special Publications, Berkeley, CA, 17 pp.

Neves, S.P., Mariano, G., Correria, P.B., Silva, J.M.R., 2006. 70 m.y. of synorogenic plutonism in eastern Borborema Province (NE Brazil): temporal and kinematic constraints on the Brasiliano Orogeny. Geodinamica Acta $19,213-236$

Paterson, S.R., Fowler Jr., T.K., Schmidt, K.L., Yoshinobu, A.S., Yuan, E.S., Miller, R.B., 1998. Interpreting magmatic fabric patterns in plutons. Lithos 44, 53-82. 
Pereira, M.F., Silva, J.B., 2004. Development of local orthorhombic fabrics within a simple-shear dominated sinistral transpression zone: the Arronches sheared gneisses (Iberian Massif, Portugal). In: Alsop, G.I., Holdsworth, R.E., McCaffrey, K.J.W., Hand, M. (Eds.), Flow Processes in Faults and Shear Zones, 224. Geological Society, London, pp. 215227. Special Publications.

Rosenberg, C.L., 2004. Shear zones and magma ascent: a model based on a review of the Tertiary magmatism in the Alps. Tectonics, 23, TC3002. doi: 10.1029/2003TC001529.

Robin, P.-Y.F., 2002. Determination of fabric and strain ellipsoids from measured sectional ellipses - theory. Journal of Structural Geology 24, 531-544.

Stacey, J.S., Kramers, J.D., 1975. Approximation of terrestrial lead isotope evolution by a two stage model. Earth and Planetatry Science Letters 26, 207-221.

Vauchez, A., Silva, M.E., 1992. Termination of a continental-scale strike-slip fault in partially melted crust: the West Pernambuco shear zone, northeast Brazil. Geology 20, 1007-1010.
Vauchez, A., Neves, S.P., Caby, R., Corsini, M.E., Silva, M., Arthaud, M., Amaro, V.E., 1995. The Borborema shear zone system, NE Brazil. Journal of South American Earth Sciences 8, 247-266.

Vauchez, A., Neves, S.P., 1997. Transcurrent shear zones and magma emplacement in Neoproterozoic belts of Brazil. In: Bouchez, J.L., et al. (Eds.), Granite: From Segregation of Melt to Emplacement Fabrics. Kluwer, Boston, pp. 275-293.

Weinberg, R.F., Sial, A.N., Mariano, G., 2004. Close spatial relationship between plutons and shear zones. Geology 32 (5), 377-380.

Williams, I.S., Claesson, S., 1987. Isotopic evidence for the Precambiran provenance and Caledoniam metamorphism of high grade paragneisses from Seve Nappes, Scandinavian Caledonides. II. Ion microprobe zircon U-Th-Pb. Contribution to Mineralogy and Petrology 97, 205-217.

Williams, I.S., 1998. U-Th-Pb geochronology by ion microprobe. In: McKibben, M.A., Shanks, W.C., Ridley, W.I. (Eds.), Applications of Microanalytical Techniques to Understanding Mineralizing Processes. Reviews in Economic Geology, 7, pp. 1-35. 